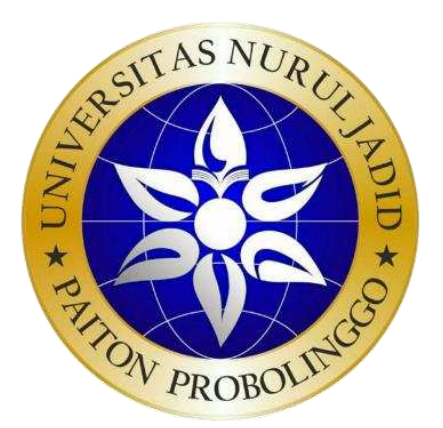

\title{
ASUHAN KEPERAWATAN PADA PASIEN DENGAN AMPUTASI
}

\author{
BUKU AJAR
}

OLEH:

SETIYO ADI NUGROHO. Ns.,M.Kep.

FAKULTAS KESEHATAN

UNIVERSITAS NURUL JADID

2021 


\section{KATA PENGANTAR}

Puji syukur kehadirat Allah SWT atas rahmat dan hidayah-Nya kami dapat menyelesaikan Buku Ajar kami yang berjudul "Asuhan Keperawatan Pada Pasien dengan Amputasi”. Buku Ajar ini sebagai sumber referensi dan bahan mengajar di kelas Keperawatan Medikal Bedah. Buku Ajar ini menjelaskan tentang teori Amputasi, pendekatan dalam proses ilmu keperawatan dan asuhan keperawatan.

Penulis menyadari bahwa dalam proses penulisan buku ini masih jauh dari kesempurnaan baik materi maupun cara penulisannya. Namun demikian, penulis telah berupaya dengan segala kemampuan dan pengetahuan yang dimiliki sehingga buku ini dapat selesai dengan baik. Oleh karena itu, kritik dan saran yang membangun sangat berarti bagi kami. Besar harapan kami semoga buku ini dapat menambah pengetahuan dan wawasan serta memberi manfaat bagi pembaca. Aamiin.

Probolinggo, Agustus 2021

Setiyo Adi Nugroho. Ns., M. Kep. 


\section{DAFTAR ISI}

\section{Kata Pengantar}

Daftar Isi

1. Definisi

4

2. Epidemiologi

3. Etiologi



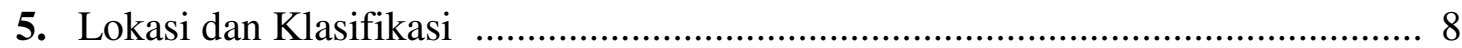



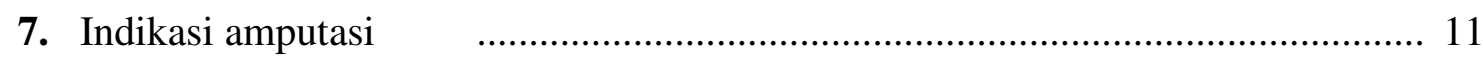

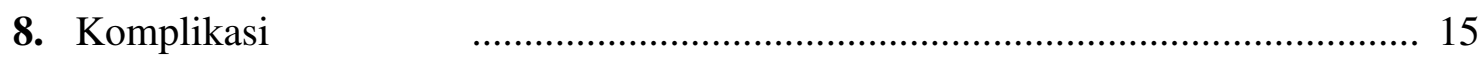

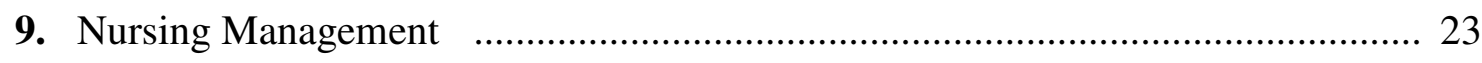





\section{Daftar Pustaka}




\section{KONSEP TEORI}

\section{ASUHAN KEPERAWATAN PASIEN DENGAN AMPUTASI}

\section{Definisi}

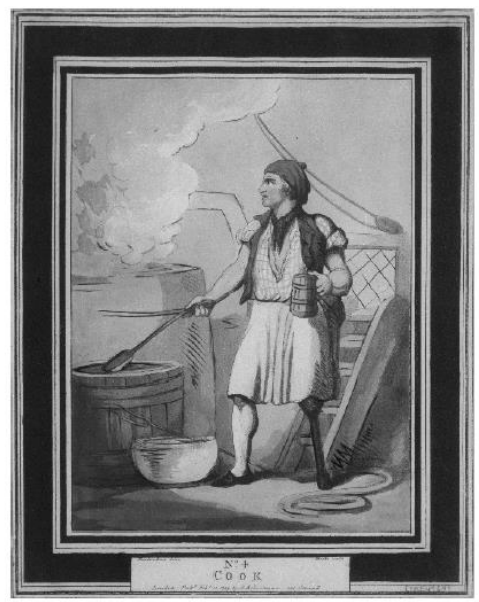

Ship's cook with peg-leg after be

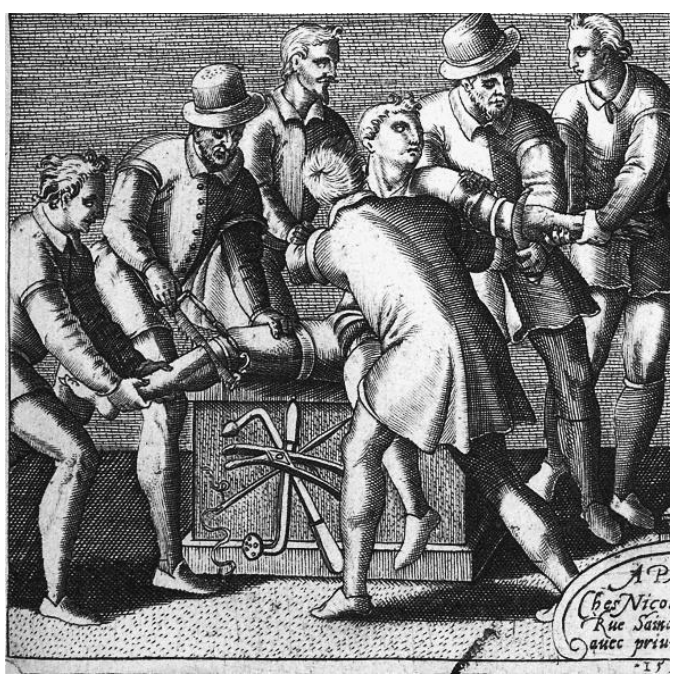

Amputasi merupakan prosedur pembedahan yang paling tertua, perkembangan tenik pembedahan dan desain prosthetic dimulai akibat dari peperangan (Daniels \& Nicoll, 2012b). Istilah amputasi berasal dari bahasa latin yaitu "amputare", mengacu didalam teks romawi yaitu pemotongan tangan para penjahat. Pada abad ke-17 penulis dari Inggris Cook dan Wiseman menerapkan amputasi sebagai pengangkatan ekstermitas dalam menangani tumor tulang ganas (Kirkup, 2007). Sampai sekarang Amputasi diartikan sebagai penghilangan anggota tubuh. Ini mungkin terjadi sebagai akibat dari trauma (trauma amputasi) atau dalam upaya untuk mengendalikan penyakit atau kecacatan (amputasi terapi) (Timby \& Smith, 2010). Salah satu indikasi untuk dilakukan amputasi adalah iskemia ireversibel yang disebabkan salah satu penyakit atau trauma (Daniels \& Nicoll, 2012b).

Lebih jelas lagi dijabarkan Amputasi merupakan pengangkatan bagian tubuh, sering pada ekstremitas. Amputasi ekstremitas bawah sering diperlukan karena penyakit progresif vaskular perifer (diabetes mellitus), fulminan gas gangren, trauma (crushing injury, luka bakar, frostbite, luka bakar listrik, ledakan, luka balistik), cacat bawaan, osteomyelitis kronis, atau tumor ganas. Dari semua penyebab tersebut, penyakit pembuluh darah perifer menyumbang sebagian amputasi ekstremitas bawah. Amputasi ekstremitas atas 
terjadi lebih jarang daripada ekstremitas bawah dan paling sering diperlukan karena baik luka trauma atau tumor ganas (Smeltzer, Hinkle, Bare, \& Cheever, 2010).

\section{Epidemiologi}

Menurut informasi dari National Limb Loss Information Center (NLLIC) tahun 2008, ada sekitar 1,7 juta orang di Amerika Serikat hidup dengan kehilangan anggota tubuh dan sekitar 185.000 pembuangan rumah sakit yang terkait dengan amputasi setiap tahun. Jumlah kasus baru amputasi tertinggi pada pasien pada diabetes, terdapat 1 dari setiap 185 pasien diabetes menjalani amputasi digit atau anggota tubuh lainnya kekurangan anggota tubuh akibat congenital sebesar 2.6 per 10.000 kelahiran hidup (National Limb Loss Information Center (NLLIC), 2008).

\section{Etiologi}

Indikasi amputasi yang paling sering untuk ekstremitas bawah adalah penyakit pembuluh darah perifer, lebih dari setengah dari amputasi dikaitkan dengan diabetes mellitus. Trauma adalah penyebab utama amputasi pada populasi yang lebih muda dan lebih sering terjadi pada pria karena paparan lebih tinggi terhadap bahaya kerja. Amputasi juga dapat diindikasikan pada luka bakar termal ataupun listrik, frostbite yang parah, dan gangren. Tumor ganas juga dapat menjadi penyebab amputasi, tetapi hal ini jarang terjadi karena kemajuan dalam penyelamatan ekstremitas (Daniels \& Nicoll, 2012b). Infeksi tulang dan jaringan yang berlangsung lama (Timby \& Smith, 2010).

\section{Patofisiologi}

Pada Peripheral Vascular Disease bagian kelompok otot yang terlibat (biasanya otot betis) tidak menerima suplai darah arteri yang cukup baik karena obstruksi atau sumbatan. Pada penderita diabetes mellitus, suplai darah yang tidak memadai ini disebabkan oleh arteriosklerosis. Kekurangan darah akan menyebabkan iskemia irreversible. Dalam trauma, setiap usaha dilakukan untuk menyelamatkan anggota badan, dengan satu-satunya indikasi mutlak untuk amputasi sebagai cedera vaskular yang tidak dapat diperbaiki (Daniels \& Nicoll, 2012b). 


\section{Penyakit Peripheral Vascular}

Penyakit diabetes berdampak pada pembuluh darah secara keseluruhan. Perubahan Metabolisme berkaitan dengan kondisi hiperglikemia mengakibatkan perubahan struktur dan fungsi arteri pada jaringan, sel, dan tingkat molekuler. Secara spesifik, DM merupakan kondisi pro-inflamasi, terbukti dengan peningkatan C-reaktif protein (CRP), baik yang berhubungan dengan DM ataupun PAD. Lebih dari inflamasi marker, CRP mengikat reseptor sel endotel dan memiliki efek berbagai molekul, termasuk menghambat endotel nitrit oksida sintase (eNOS), menstimulasi produksi tissue faktor, dan meningkatkan produksi anti fibrinolitik faktor termasuk plasminogen activator inhibitor (PAI) -1. Pada penderita diabetes, perubahan pada metabolisme NO terjadi akibat hiperglikemia dan resistensi insulin. Akibat langsung dari suatu keadaan proinflamasi yang pada akhirnya mengarah pada pembentukan ateroma melalui jalur molekuler dan seluler yang sudah mapan.

Arteri terdiri dari tiga lapisan Selaput tunika intima, media, dan adventitia. Tunika tunika intima adalah lapisan terdalam dengan sisi luminal yang terdiri dari satu lapisan sel endotel. Lapisan berikutnya intima terdiri dari matriks jaringan ikat ekstraseluler terutama terdiri dari proteoglikan dan kolagen. Di sekitar intima merupakan lamina elastis internal yang terdiri dari sel-sel elastis yang bervariasi ketebalannya tergantung pada ukuran pembuluh. Media tunika merupakan lapisan berikutnya yang terdiri dari vaskular utama sel otot polos dan ini lapisan yang tebal dari pembuluh darah. Lapisan ini dikelilingi oleh lamina elastis eksternal, yang memisahkan media tunika adventitia dari tunika, lapisan terluar dari dinding pembuluh darah. Lapisan ini terutama terdiri atas kolagen dengan diselingi fibroblas dan sel-sel otot polos pembuluh darah.

Perkembangan aterosklerosis yang berhubungan dengan diabetes sama halnya seperti aterosklerosis pada pasien nondiabetes. termasuk cedera endotel, proliferasi sel otot polos, perkembangan sel busa dan infiltrasi, aktivasi trombosit, dan meningkatnya peradangan. lokasi lesi ditentukan oleh kekuatan perubahan hemodinamik dan sumber eksternal cedera pada sel-sel endotel. Meningkatnya permeabilitas endotel menyebabkan retensi yang merusak low-density lipoprotein (LDL) yang saling berinteraksi dengan dasar matriks ekstraseluler (ECM). Interaksi tersebut mempertahankan LDL pada dinding pembuluh di mana ia dapat mengalami oksidasi dengan reactive oxygen species 
(ROS). LDL yang teroksidasi ini kemudian dapat merangsang sel-sel endotel atasnya untuk upregulate molekul adhesi selular, protein chemotactic, growth factor, dan menghambat produksi nitrat oksida (NO). Kegiatan ini merekrut monosit dan makrofag, yang interaksi dengan kumpulan LDL teroksidasi tinggi untuk membentuk sel busa. Proinflamasi memproduksi sitokin oleh makrofag aktif sehingga menstimulasi proliferasi sel otot polos pada pembuluh darah. Sel-sel otot polos intima kemudian menghasilkan ECM yang menimbulkan cap fibrosa. Pada akhirnya terjadi plak yang kompleks sangat rentan terhadap ketidakstabilan, ruptur, dan trombosis yang tumpang tindih menyebabkan oklusi vaskular akut.

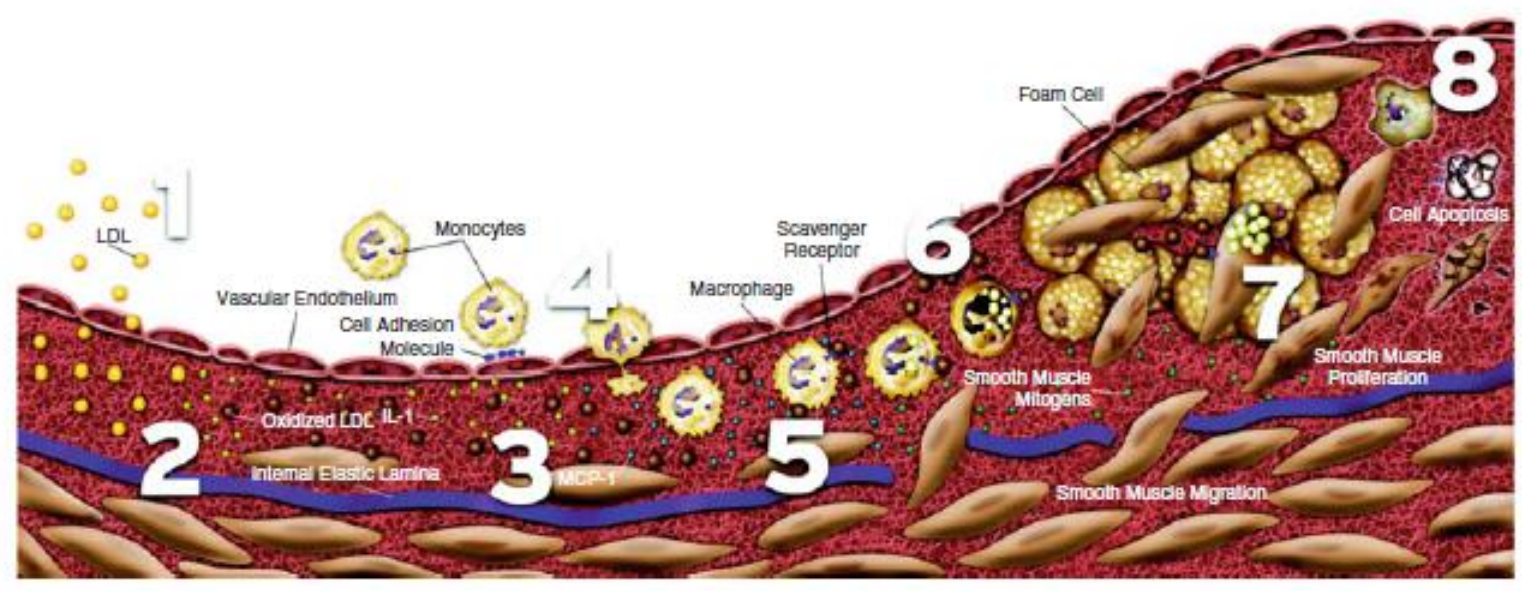

Fig. 2.1 The stages of development of an atherosclerotic plaque. (1) LDL is taken up by the endothelium. (2) Oxidation of LDL by macrophages and VSMCs. (3) Release of growth factors and cytokines. (4) Attraction of additional monocytes. (5) Foam cell accumulation. (6) SMC proliferation.
$(7,8)$ Formation of plaque [reprinted from Faxon DP, Fuster V, Libby P. Atherosclerotic vascular disease conference: Writing Group III: Pathophysiology. Circulation. 2004;109(21):2617-25. With permission from Lippincott Williams \& Wilkins] 


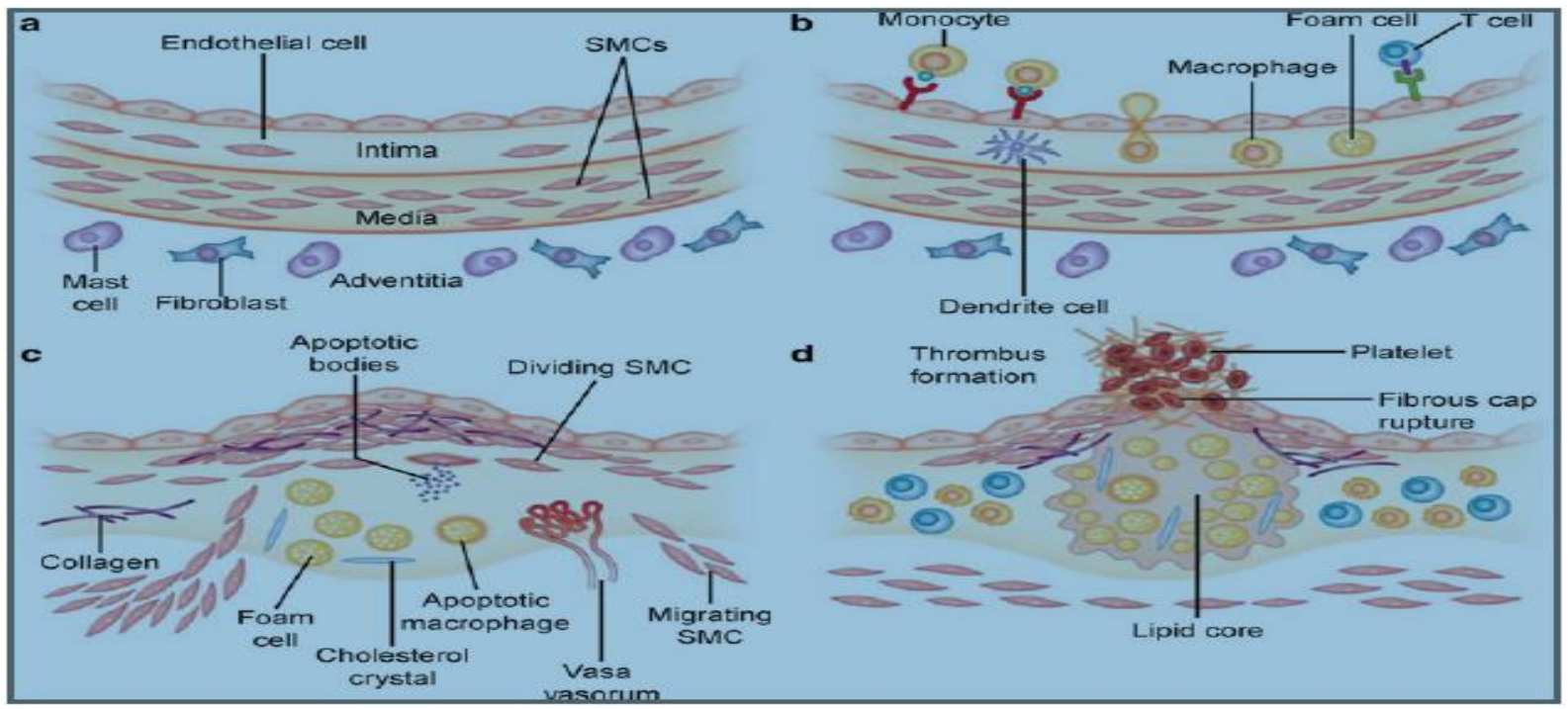

Fig. 2.2 Development of atherosclerotic plaque with the biology of atherosclerosis. Nature. 2011;473(7347): superimposed thrombus [reprinted from Libby P, Ridker 317-25. With permission from Nature Publishing PM, Hansson GK. Progress and challenges in translating Groupl

Plak aterosklerotik dengan adanya diabetes pada umumnya mengalami peningkatan pengapuran, core nekrotik, reseptor untuk advanced glikosilasi produk akhir (RAGE), dan makrofag dan infiltrasi sel-T. Ada pula tingkat kejadian plak pecah dapat sembuh dan remodeling vaskuler. Fitur tersebut dapat berkontribusi untuk atherosclerosis lebih parah dan lebih tinggi insiden komplikasi yang akut (Shrikhande \& McKinsey, 2012).

\section{Lokasi dan Klasifikasi}

Amputasi dilakukan pada bagian paling distal yang dapat memulihkan dengan sukses.

Lokasi amputasi ditentukan oleh dua faktor: sirkulasi dan manfaat fungsional (yaitu, memenuhi persyaratan untuk penggunaan prostesis). Status sirkulasi ekstremitas dievaluasi melalui pemeriksaan fisik dan pemeriksaan diagnostik. Otot dan perfusi kulit sangat penting untuk penyembuhan. Pemeriksaan aliran darah dengan USG duplex / doppler, penentuan segmental tekanan darah, dan transkutan $\mathrm{PaO} 2$ ekstremitas ini 
termasuk alat bantu diagnostik sangat berharga. Angiography ini dilakukan jika revaskularisasi dianggap salah satu pilihan.



Tujuan operasi merupakan untuk mempertahankan lebih banyak panjangnya ekstremitas yang diperlukan untuk menjaga fungsi dan mungkin juga untuk mencapai prostetik yang sesuai. Pelestarian lutut dan siku sendi yang diinginkan. Gambar disamping memperlihatkan tingkatan di mana ekstremitas dapat diamputasi. Sebagian besar amputasi yang melibatkan ekstremitas dapat nantinya dipasang dengan protesa.

Amputasi jari kaki dan bagian pada kaki dapat menyebabkan perubahan gaya berjalan dan keseimbangan. Amputasi Syme (modifikasi disartikulasi ankle amputasi) ini dilakukan paling sering untuk trauma kaki yang luas dan ini bertujuan untuk mempertahankan ujung ekstremitas yang mampu menahan penuh berat badan. Belowknee amputation (BKA) lebih disukai daripada above-knee amputation (AKA) oleh karena betapa pentingnya sendi lutut dan tenaga yang dibutuhkan untuk berjalan.

Disarticulations Knee yang paling berhasil pada usia muda, pasien yang aktif yang dapat mengembangkan kontrol secara tepat untuk prostesis. Ketika AKAs yang dilakukan, memungkinkan dipertahankan panjang ekstermitas, otot yang stabil dan berbentuk, dan kontraktur pinggul akan dicegah untuk memaksimalkan potensi ambulatori. Kebanyakan orang yang memiliki hip disartikulasi amputasi harus bergantung pada kursi roda untuk mobilitas. 




Amputasi ekstremitas atas yang dilakukan dengan tujuan mempertahankan panjang fungsional maksimal. Prostesis dipasang lebih awal untuk memastikan berfungsi yang maksimal. Amputasi bertahap bisa dilakukan ketika terdapat gangren serta infeksi. tahap awal dilakukan amputasi guillotine (misalnya, anggota tubuh tidak tertutup) ini dilakukan untuk menghilangkan nekrotik dan jaringan terinfeksi. Luka debridement dan dibiarkan mengalir. Sepsis diobati dengan antibiotik sistemik. Dalam beberapa hari, setelah infeksinya telah dikendalikan dan kondisi pasien telah stabil, pada amputasi definitif dengan penutupan kulit ini dilakukan (Smeltzer et al., 2010).

Amputasi diklasifikasikan berdasarkan ekstremitas yang terkena dan tingkat amputasi. Amputasi pada tangan disebut below-the-elbow amputation (BEA), amputasi lengan bawah dan pada lengan atas disebut above-the-elbow amputation (AEA). Amputasi kaki bisa below-the-knee amputation (BKA) atau above-the knee amputation (AKA). Terkadang, hanya jari atau jari kaki yang diamputasi. Contoh dari penjelasan ini adalah "amputasi jari pertama, tangan kanan, bawah ruas jari kedua (Rosdahl \& Kowalski, 2012). 


\section{Manifestasi klinik}

Jika amputasi disebabkan penyakit kronis, Riwayat kesehatan medis sebelumnya pasien harus diperiksa untuk mengetahui penyebab amputasi atau amputasi yang akan terjadi. Jika penyebabnya adalah penyakit peripheral vascular, pasien harus dikaji untuk riwayat klaudikasio intermiten, yang meliputi nyeri (biasanya pada otot betis) nyeri berkurang saat istirahat. Pasien harus ditanya tentang keberadaan nyeri pada jari-jari kaki dan kakinya pada saat istirahat yang dapat membaik dengan menempatkan ekstremitas dalam posisi tergantung. Lain halnya penyebabnya berasal dari trauma atau luka bakar, mekanisme cedera diperoleh (Daniels \& Nicoll, 2012b).

Penyakit pembuluh darah perifer menyebabkan iskemia jaringan distal seperti tungkai dan kaki. Gangren dan amputasi bisa terjadi. Tanda-tanda gangguan sirkulasi arteri perifer di kaki dan kaki mungkin termasuk yang berikut (Berman, Snyder, \& Frandsen, 2016):
a. Penurunan denyut nadi perifer
b. Nyeri atau parestesia
c. Warna kulit pucat
d. ekstremitas dingin
e. Penurunan Distribusi rambut

\section{Indikasi Amputasi}

Adapun indikasi amputasi yaitu penyakit vascular perifer yang tidak dapat direkonstruksi dengan nyeri iskemik atau infeksi yang tidak dapat ditoleransi lagi, nyeri atau infeksi yang tidak dapat di toleransi lagi dalam pasien yang tidak dapat bergerak dengan penyakit vaskuler perifer, infeksi yang menyebar secara luas dan tidak responsive terdapat terapi konservatif, tumor yang responsnya buruk terhadap terapi nonoperatif, trauma yang cukup luas sehingga tidak memungkinkan untuk direparasi.

Adapun tujuan amputasi sebagai berikut:

a. Live saving (menyelamatkan jiwa), contoh trauma disertai keadaan yang mengancam jiwa (perdarahan dan infeksi).

b. Limb saving (memanfaatkan kembali kegagalan fungsi ekstremitas secara maksimal), seperti pada kelainan kongenital dan keganasan. 
Pada amputasi traumatik, tujuan utamanya adalah untuk menyelamatkan dan menempelkan kembali ekstremitas. Banyak pedoman dan sistem penilaian telah dibentuk untuk membantu dalam menentukan anggota badan yang diselamatkan. Salah satu sistem yang paling banyak digunakan adalah mangled extremity severity score (MESS). Ketika amputasi dilakukan karena trauma, jaringan yang terkontaminasi harus debridement dan irigasi untuk mengurangi risiko infeksi. Seringkali jenis amputasi akan dibiarkan terbuka untuk memungkinkan debridement lebih lanjut, dan penutup kulit ditutup di lain waktu. Jika ada tidak cukup untuk membuat jaringan flaps untuk menutup luka, perbaikan tulang dan pencangkokan kulit mungkin diperlukan (Daniels \& Nicoll, 2012a).

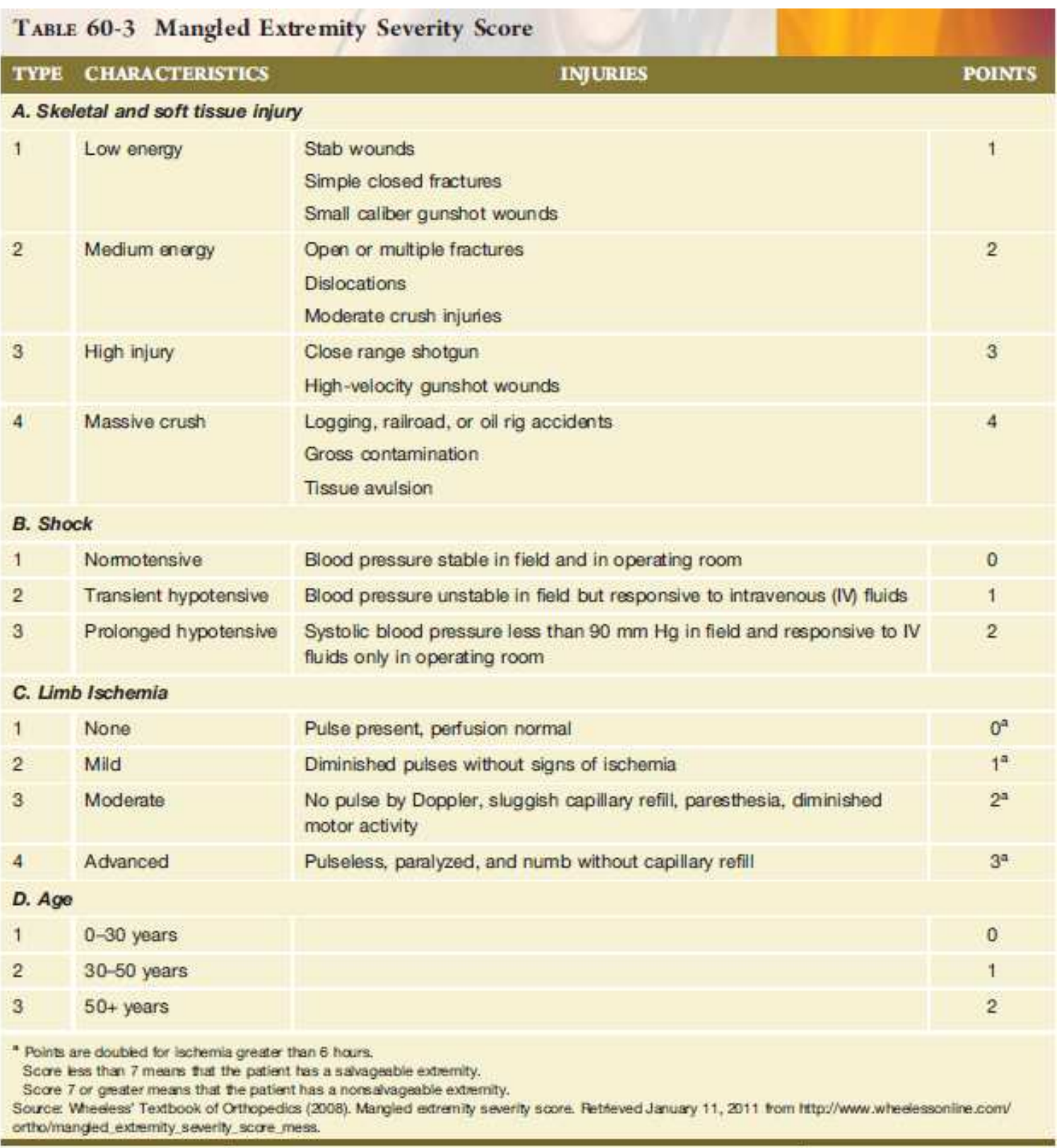




\section{Tipe Amputasi}

Amputasi bisa dilakukan dengan menggunakan metode terbuka atau tertutup. Dalam amputasi terbuka (amputasi guillotine), akhir tungkai sisa (atau stump) sementara terbuka tanpa kulit yang menutupi itu. Terbuka amputasi biasanya dilakukan dalam kasus-kasus infeksi. Traksi kulit diaplikasikan, dan daerah yang terinfeksi dibiarkan mengalir. Traksi tersebut harus kontinu. Dokter bedah dapat mengatur traksi sehingga klien dapat mobilisasi di tempat tidur.

Pada amputasi tertutup lebih sering terjadi (flap amputasi), flaps kulit menutupi ujung tulang terputus. Pasien dengan amputasi tertutup kembali dari operasi dengan dreesing kompresi lembut atau shell plester yang kaku mencakup sisa tungkai. Compression dressing terdiri perban dengan elastic roller bandage untuk menciptakan tekanan untuk mengontrol perdarahan. Bisa jadi ada pylon walking, jenis prostesis bersifat sementara tersusun dari pos berbahan logam dan cetakan kaki. terpasang ke shell plester yang kaku.

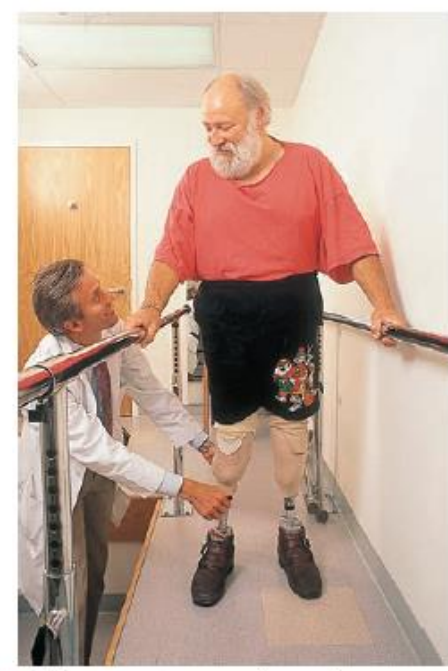

FIGURE 61-8. Many amputees receive prostheses soon after

surgery and begin learning how to use them with the help and

support of the rehabilitation team, which includes nurses,

physicians, physical therapists, and others.

Amputasi bertahap direncanakan ketika klien mengalami infeksi parah dan gangren. Metode guillotine pertama kali digunakan, dan kemudian beberapa hari kemudian, setelah infeksi diobati dan klien stabil, lebih banyak definitif, menutup amputasi dilakukan.

a. Arm Amputation 
Lengan mempunyai fungsi yang sangat khusus. Akibatnya, amputasi lengan, khususnya lengan dengan tangan yang dominan, membutuhkan penyesuaian fisik dan emosional selama preoperatif serta periode pasca operasi. Untungnya, sebagian besar klien dengan lengan amputasi dapat diukur selama prostesis segera setelah menyembuhkan bekas luka operasi.

Tiga jenis prostesis yang tersedia untuk lengan yang diamputasi: harness bahu dengan kabel yang yang menempel pada perangkat terminal mekanik, disebut sebagai pengait; semi berfungsi tangan kosmetik yang dapat digantikan untuk hook; dan lengan myoelectric. Hook melakukan fungsi tangan dan jari ketika diamputasi menggerakkan skapula dan berekspansi di dada, mengaktivasi kabel yang terpasang dari harness bahu ke perangkat mekanis. Perangkat terminal mekanik cukup kuat, kokoh, dan fungsional. Tangan kosmetik, yang dapat terpasang ke kabel yang yang sama seperti hook, memiliki penampilan tangan alami, tetapi tidak memiliki kemampuan untuk melakukan keterampilan motorik halus. Lengan myoelectric memiliki tangan yang realistis tampak yang akan diaktifkan oleh impuls listrik dari otot-otot di lengan atas. Aktivitas listrik relay dari elektroda di kulit prostesis untuk microcircuits di jari prostetik. Lengan myoelectric memiliki tiga keunggulan: menghilangkan kebutuhan untuk mengenakan harness, perangkat terminal terlihat natural, dan memiliki fungsi agak lebih baik daripada tangan kosmetik. Meskipun keuntungan, lengan myoelectric tidak kasar cukup untuk melakukan pekerjaan perangkat terminal mekanik.

b. Leg Amputation

Amputasi kaki adalah operasi lebih umum daripada amputasi lengan. AK amputasi lebih melumpuhkan daripada amputasi BK; Oleh karena itu, kecuali jika bukti menunjukkan bahwa lutut tidak bisa diselamatkan, setiap usaha dilakukan untuk amputasi bawah lutut.

Tren ini untuk memiliki prostesis temporer terpasang ke shell plester mencakup tungkai sisa bawah segera setelah operasi. Hal ini mengurangi trauma psikologis bagi klien karena mempromosikan arti yang lebih secara utuh citra tubuh setelah operasi. Juga, tiang berjalan memfasilitasi ambulasi awal. Segera, klien diperbolehkan untuk berdiri dan meletakkan yang terbatas memberi beban pada ekstremitas yang tersisa. 
Sebagai menyembuhkan stump dan edema menghilang, cast kedua dapat kembali diterapkan atau soket temporer yang terbuat dari polypropylene ringan dapat dibentuk. Pada akhirnya, prostesis konvensional custom-made agar sesuai dengan tunggul serta kebutuhan klien. Kaki yang prostesis dapat diadakan di tempat dengan cara sabuk panggul atau hisap.

Pada pelaksanaannya amputasi, dilakukan sebagian kecil sampai dengan sebagian besar dari tubuh, dengan dua metode :

\section{a. Amputasi Terbuka (guillotine amputasi).}

Metode ini digunakan pada klien dengan infeksi yang berat, dimana pemotongan pada tulang dan otot pada tingkat yang sama. Bentuknya benar-benar terbuka dan dipasang drainage agar luka bersih, dan luka dapat ditutup setelah tidak terinfeksi.

\section{b. Amputasi Tertutup (flap amputasi)}

Pada metode ini, dibuat skaif kulit untuk menutup luka yang dibuat dengan memotong kurang lebih 5 sentimeter dibawah potongan otot dan tulang, kulit tepi ditarik pada atas ujung tulang dan dijahit pada daerah yang diamputasi.

Berdasarkan pelaksanaan, amputasi dibedakan menjadi :

a) Amputasi selektif atau terencana.

Amputasi jenis ini dilakukan pada penyakit yang terdiagnosis dan mendapat penanganan yang baik serta terpantau secara terus-menerus. Amputasi dilakukan sebagai salah satu tindakan alternatif terakhir.

b) Amputasi akibat trauma.

Merupakan amputasi yang terjadi sebagai akibat trauma dan tidak direncanakan. Kegiatan tim kesehatan adalah memperbaiki kondisi lokasi amputasi serta memperbaiki kondisi umum klien.

c) Amputasi darurat.

Kegiatan amputasi dilakukan secara darurat oleh tim kesehatan. Biasanya merupakan tindakan yang memerlukan kerja yang cepat seperti pada trauma dengan patah tulang multiple dan kerusakan/kehilangan kulit yang luas.

\section{Komplikasi}

Hematoma, perdarahan dan infeksi adalah komplikasi yang berpotensi pada saat pasca operasi. Termasuk osteomilitis kronis (setelah infeksi persisten), burning pain 
(causalgia). Nyeri disebabkan oleh neuroma stump, yang disebabkan terjepitnya ujung saraf karena adanya proses pembentukan scar. Hal ini dapat diatasi dengan suntikan procain, anestesi local atau re-amputasi (Timby \& Smith, 2010).

Komplikasi dari referensi lain meliputi hemorrhage, infeksi, kerusakan kulit, phantom limb pain, dan kontraktur sendi. Oleh karena pembuluh darah utama yang telah terputus, perdarahan masif dapat terjadi. Infeksi merupakan resiko dengan semua prosedur bedah. Risiko infeksi meningkat dengan luka terkontaminasi setelah amputasi traumatik. Iritasi pada kulit disebabkan oleh prosthesis dapat mengakibatkan kerusakan kulit. Phantom limb pain disebabkan oleh pemutusan saraf perifer. Joint Contracture ini disebabkan oleh penentuan posisi dan suatu pola penarikan fleksi protektif yang terkait dengan rasa sakit dan ketidakseimbangan otot (Smeltzer et al., 2010).

\section{a. Neuroma}

Insiden cedera saraf perifer diperkirakan $1,6-2,8 \%$ pada pasien dengan trauma ekstremitas atas maupun bawah. Sekitar 3-5\% dari semua pasien yang terlibat dalam cedera saraf perifer mengembangkan neuroma simtomatik. Di Belanda, ada sekitar 3,5 / 100.000 atau 580 kasus baru nyeri neuropatik disebabkan oleh trauma atau cedera saraf iatrogenik setiap tahunnya. Gejala Neuromas seperti rasa terbakar, shooting atau nyeri listrik serta ambang diturunkan untuk nyeri (hiperalgesia) dan nyeri pada sentuhan (allodynia) atau rasa dingin yang ringan (intoleransi dingin).

Cedera saraf perifer menyebabkan sejumlah respon seluler. Cedera Akson distal mengalami degenerasi dan sel lokal Schwann dan makrofag membersihkan tuba endoneurial bagian distal dari apoptotic debris. Hal ini disebut Wallerian degeneration. Ujung akson terputus mulai tumbuh dalam waktu 24 jam setelah cedera, dan akson individu dapat menghasilkan lebih dari satu tunas. Neurotropik Faktor (yaitu BDNF, NGF), dirilis oleh makrofag dan sel Schwann, mengarahkan regenerasi akson dan menginduksi maturasi akson dan perpanjangan kedalam selubung endoneurial. Laju perkembangan akson adalah 1-5 mm / hari, dan, oleh karena itu, mungkin memakan waktu beberapa bulan untuk regenerasi akson ke reinnervate target bagian distal. Besarnya celah yaitu lebih $15-30 \mathrm{~mm}$, biasanya tidak dapat dijembatani oleh akson. Proliferasi fibroblas dan jaringan parut yang baru terbentuk dapat membentuk blokade fisik. Ketika terdapat blokade antara stump 
proksimal dan bagian distal, atau stump bagian distal hilang misalnya dalam kasus amputasi, proliferasi saraf berlanjut dengan kemungkinan tinggi pembentukan neuroma.

Figure 1. Wallerian degeneration
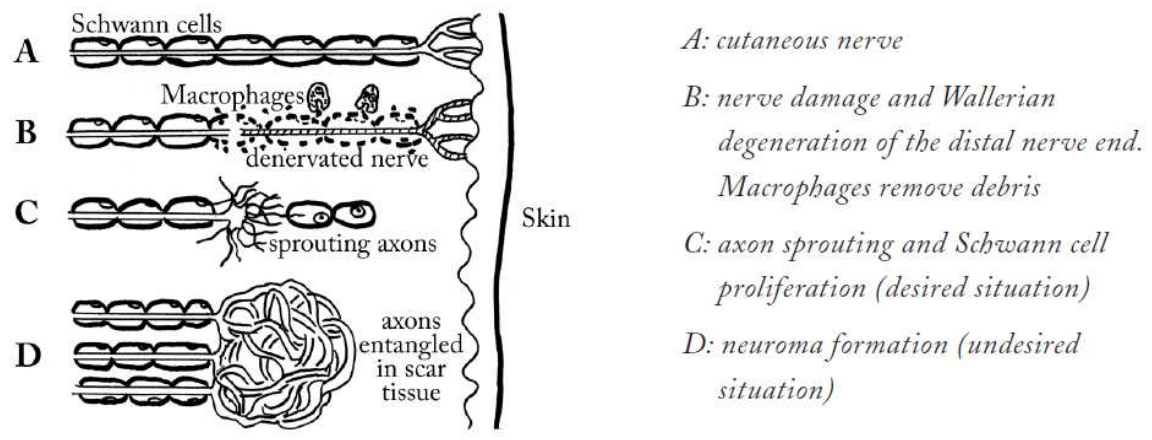

Dalam neuromas simtomatik, ada sensitisasi serabut saraf nociceptive karena upregulasi saluran natrium, adrenergik dan reseptor kolinergik nikotinik. Selain itu, konduksi ephaptic atau "cross-talk" antara serabut saraf yang berdekatan dapat berlangsung menyebabkan sensitivitas abnormal dan aktivitas spontan dari akson di neuroma tersebut. Seperti ektopik masukan saraf perifer berlanjut, perubahan struktur saraf yang terlibat dalam persepsi nyeri, yaitu ganglion akar dorsal, tanduk dorsal sumsum tulang belakang, thalamus dan korteks sensorik, mulai berlangsung: Ada peningkatan rangsangan neuron di segmen tulang belakang yang berdekatan dan daerah kortikal, juga disebut 'sensitisasi sentral.

Selain itu, ada peningkatan bukti bahwa hiperalgesia mekanik dan termal dan allodynia independen nyeri spontan yang berasal dari neuroma perifer. Hal ini menunjukkan perekrutan akson dari saraf yang berdekatan, perubahan dalam pengolahan rangsangan dari tetangga serabut saraf yang utuh, atau cedera langsung ke sekitarnya cabang saraf (Stokvis, 2010).

\section{b. Phantom Sensation dan phantom pain}

Literatur yang diterbitkan secara rutin membedakan antara phantom "sensasi" dan phantom "nyeri". Weinstein, misalnya, telah mengusulkan bahwa sensasi phantom dapat dibagi menjadi 3 kategori: sensasi kinetik, komponen kinestetik, dan persepsi exteroceptive. Sensasi kinetik adalah persepsi gerakan, dengan persepsi memperhatikan kedua gerakan spontan dan berkemauan keras. Sebaliknya, 
komponen kinestetik mengacu pada ukuran, bentuk, dan posisi bagian tubuh yang hilang, sedangkan persepsi exteroceptive termasuk sentuhan, tekanan, suhu, rasa gatal, dan getaran. Weinstein menjelaskan nyeri phantom sebagai jatuh di bawah kategori "persepsi exteroceptive," tapi membedakan nyeri dari sensasi, menyatakan bahwa nyeri phantom memiliki intensitas yang lebih besar dibandingkan sensasi phantom.

Selain itu, beberapa upaya telah dilakukan untuk membangun gambaran yang tepat atau definisi " phantom pain." Sherman dan Sherman menyimpulkan dari upaya survei bahwa karakteristik nyeri phantom dapat dibagi menjadi 4 domain: (1) intensitas sensasi rasa sakit; (2) frekuensi episode; (3) durasi setiap episode; dan (4) deskripsi rasa sakit. Karya sebelumnya dari Melzack juga berusaha untuk mengkarakterisasi nyeri phantom. Karyanya menggambarkan nyeri phantom sebagai terdiri dari 4 sifat yang berbeda: (1) persisten, bertahan lama nyeri setelah jaringan yang cedera telah sembuh; (2) terdiri dari "zona pemicu" yang berpotensi menyebar ke yang lain (sehat) bagian tubuh; (3) sering kali berkembang pada pasien yang mengalami nyeri sebelumnya di anggota badan yang terkena (lebih sering terjadi pada orang yang diamputasi sipil dibandingkan dengan amputees militer) dan seringkali menyerupai rasa sakit yang dialami sebelum amputasi; dan (4) keduanya bertambah dan berkurang masukan somatik tampaknya memiliki pengaruh positif pada rasa sakit, dan dalam beberapa kasus bahkan dapat meringankan pasien sakit phantom. Namun, meskipun berbagai upaya untuk mengklasifikasikan dan menentukan nyeri phantom, patofisiologi dan etiologi kondisi tetap menjadi misteri 



Fig. 10.1 Kinaesthetic seusations for limb amputees (a-d upper limb; e-h lower limb) (Shadow areas $=$ phantom $)$

Gambar di adopsi dari (Murray, 2010)

Ada banyak teori seputar patofisiologi dan etiologi PLP dalam literatur. Kedua mekanisme sistem saraf pusat dan perifer telah dikemukakan, dan beberapa ahli menyarankan bahwa nyeri phantom adalah kombinasi dari keduanya. Di bawah ini adalah deskripsi dari berbagai teori yang telah dikemukakan untuk menjelaskan terjadinya PLP di orang yang diamputasi.

\section{1) Central Nervous System Theories}

\section{Cortical Reorganization and Neuroplasticity}

Reorganisasi kortikal merupakan alasan yang paling sering dikutip untuk keberadaan atau perkembangan nyeri phantom. Bukti eksperimental yang ekstensif telah menunjukkan bahwa somatosensori dan motorik korteks mengalami perubahan neuroplastic mengikuti amputasi anggota tubuh. Literatur menunjukkan bahwa 
daerah kortikal yang mewakili ekstremitas yang teramputasi diambil alih oleh tetangga zona representasional baik di korteks somatosensori primer (S1) dan korteks motorik (M1).

Patrick wall adalah seorang pelopor dalam mendemonstrasikan plastisitas pada sistem saraf pusat orang dewasa. Sejak itu, model pada manusia dan hewan telah digunakan untuk menyelidiki sejauh mana reorganisasi kortikal yang terjadi pada sistem saraf pusat mengikuti deafferentation atau amputasi. Magnetoencephalography, stimulasi magnetik transkranial, pencitraan resonansi magnetik fungsional, dan stimulasi listrik langsung korteks semuanya telah digunakan untuk menunjukkan perubahan dalam peta organisasi neuron kortikal setelah amputasi. Salah satu studi hewan pertama yang membuktikan plastisitas kortikal mengikuti amputasi digunakan microelectrodes pada monyet Owl dewasa. Para peneliti menemukan bahwa ketika 1 jari diamputasi, input sensorik dari yang berdekatan digit mengambil alih. Selain itu, jumlah reorganisasi kortikal telah ditemukan untuk menjadi tergantung pada ukuran daerah deafferented (s); semakin besar deafferentation, semakin besar reorganisasi kortikal.

Ramachandran et al, menggunakan magnetoencephalography untuk menunjukkan reorganisasi kortikal pada manusia mengikuti amputasi. Mereka meneliti 4 orang yang diamputasi ekstremitas atas, dan menetapkan bahwa peta Penfield, yang menunjukkan organisasi korteks sensorimotor pada manusia, dapat direorganisasi oleh setidaknya 2 atau $3 \mathrm{~cm}$ di otak orang dewasa. Temuan mereka adalah yang pertama untuk mengkonfirmasi bahwa reorganisasi skala besar topografi dapat terjadi selama beberapa sentimeter di otak orang dewasa. Selain itu, Flor et al, melakukan studi pencitraan, telah mengkonfirmasikan bahwa ada hubungan antara S1 reorganisasi dan intensitas PLP semakin besar tingkat S1 reorganisasi, lebih intens pengalaman PLP. Satu studi lain yang digunakan functional magnetic resonance imaging untuk mempelajari tangan dan bibir yang utuh gerakan, serta gerakan ekstremitas phantom, di 14 orang yang diamputasi ekstremitas atas. Data ini dibandingkan dengan kelompok kontrol yang sehat yang dilakukan gerakan tangan dan bibir, serta gerakan tangan yang dibayangkan. Pasien dengan PLP adalah satusatunya kelompok untuk menunjukkan daerah reorganisasi S1 dan M1. Selama 
gerakan bibir, representasi wilayah bibir bergeser ke daerah yang sebelumnya berhubungan dengan tangan yang berbeda.

Seperti yang terlihat dari literatur, banyak peneliti telah menyelidiki reorganisasi kortikal sebagai penjelasan yang masuk akal untuk terjadinya PLP. Namun, teori lain juga telah mengemukakan.

\section{Body Schema}

Awalnya diusulkan oleh head dan Holmes pada tahun 1912, konsep " skema tubuh " mengacu pada representasi terus menerus yang berubah dalam otak dari posisi yang berbeda anggota badan seseorang bisa menempati. Skema tubuh dimodifikasi oleh impuls saraf dari kulit, proprioseptif, visual, dan sistem vestibular, dan, oleh karena itu, plastik dan diperoleh seluruh pengalaman. Schwoebel et al mendefinisikan skema tubuh sebagai representasi dinamis dari posisi relatif bagian tubuh yang berasal dari beberapa sensorik dan motorik input (misalnya, proprioseptif, vestibular, taktil, visual, efference copy salinan saraf perintah gerak) yang berinteraksi dengan sistem motorik dengan menghasilkan atau memulai gerakan dan aksi. Skema tubuh dapat dianggap sebagai template dari seluruh tubuh, dan perubahan tubuh seperti hasil amputasi dalam persepsi phantom limb. Studi menyelidiki kekurangan anggota tubuh congenital bahkan menyatakan bahwa otak secara alami cenderung untuk mempertahankan utuh dan berfungsi penuh dari gambar tubuh, tanpa memandang dari penampilan tubuh yang sejati. Teori ini didukung oleh hasil pengamatan yang orang yang diamputasi yang kongenital sering kali mengalami PLP.

\section{Neuromatrix Teori}

Ronald Melzack memperkenalkan "teori neuromatrix" untuk menjelaskan pengalaman yang berarti anggota badan, seperti sensasi atau nyeri phantom limb. Teori yang diusulkan dapat dianggap sebagai perluasan teori sebelumnya mengenai skema tubuh. Secara khusus, teori neuromatrix mengusulkan bahwa "body-self neuromatrix" adalah suatu jaringan neuron di dalam otak yang mengintegrasikan berbagai input dari tubuh, termasuk somatosensori, limbik, visual, dan komponen talamokortikal, dan menghasilkan pola output yang membangkitkan rasa sakit atau pengalaman yang bermakna lainnya. Neuromatrix melibatkan sensorik, afektif, dan 
dimensi kognitif dari pengalaman nyeri. Neuromatrix ini tetap mempertahankan merupakan pusat representasi setiap anggota tubuh, dan setelah pengalaman hidup, representasi ini dapat diubah atau dimodifikasi untuk account untuk setiap pengalaman baru.

Teori ini mengemukakan bahwa kesadaran internal tubuh seseorang dibuat di dalam otak, dan diaktifkan dengan berbagai masukan persepsi. Masukan yang diterima oleh otak berlimpah, dan menurut Melzack, mencakup sebagai berikut: (1) input somatosensori; (2) input visual, (3) phasic dan tonik input kognitif dan emosional; (4) intrinsic neural modulasi inhibitor; dan (5) input yang berhubungan dengan sistem stres tubuh (sistem yaitu, sitokin, endokrin, otonomi, kekebalan tubuh, dan opioid). Arsitektur tepat dari neuromatrix nyeri, namun sangat ditentukan oleh modalitas genetik dan sensorik. Istilah "neurosignature" diusulkan oleh Melzack untuk merujuk pada pola aktivitas yang dihasilkan di dalam otak yang terus diperbarui berdasarkan kesadaran seseorang dan persepsi tubuh dan diri sendiri. Melzack mengusulkan bahwa nyeri phantom disebabkan oleh perampasan berbagai masukan yang dari anggota badan ke neuromatrix, menyebabkan neurosignature yang tidak normal diproduksi.

\section{Teori tambahan}

Ramachandran dan Hirstein, Teori ini akhirnya mengarah ke versi mereka "remapping kortikal" sebagai penjelasan untuk pengembangan PLP. Namun, mengakui bahwa pemetaan tidak bisa menjelaskan seluruh kejadian PLP dalam setiap individu dengan kondisi, mereka telah mengusulkan model yang lebih mendalam tentang phantom anggota tubuh-"model multifaktorial." Dengan persepsi dalam pikiran, Ramachandran dan Hirstein menunjukkan bahwa setidaknya ada 5 sumber berbeda yang berkontribusi terhadap pengalaman PLP: (1) neuromas residu anggota tubuh; (2) pemetaan ulang kortikal; (3) monitoring discharge corollary dari perintah motorik ekstremitas; (4) seseorang body image; dan (5) memori somatik hidup sensasi nyeri atau postur anggota tubuh asli yang "dibawa" di atas ke dalam phantom tersebut. Mungkin aspek yang paling penting dari teori ini adalah penekanan bahwa semua 5 komponen bekerja sama dan saling memperkuat satu sama lain. Akibatnya, pengalaman individu dengan PLP mungkin berbeda. 


\section{2) Peripheral Nervous System Theories}

Salah satu argumen yang terkuat untuk penyebab perifer PLP muncul dari hubungan yang terlihat antara PLP dan residu nyeri limb. Pasien amputasi kronis tersisa pengalaman nyeri limb PLP secara bermakna lebih sering. Mekanisme hubungan ini tidak jelas. Namun, di bagian sisa kaki diamputasi, neuromas biasanya terbentuk di lokasi yang transeksi saraf. Neuromas ini menunjukkan aktivitas abnormal mengikuti stimulasi mekanis atau kimia. Dua penelitian telah secara independen menunjukkan bahwa sentuhan berulang hasil pada limb yg tersisa dapat meningkatkan PLP. Selain itu, penelitian telah menunjukkan bahwa PLP berkurang dengan resolusi nyeri pada limb residual. orang yang diamputasi congenital juga kadang-kadang mengalami PLP, yang berarti bahwa neuromas tidak dapat sepenuhnya menjelaskan tentang pengalaman nyeri (Weeks, Anderson-barnes, \& Tsao, 2010).

\section{Nursing Management}

Manajemen keperawatan amputasi dapat dibagi menjadi dua fungsi utama: pre operasi dan post operasi. Pada umumnya, manajemen keperawatan sebelum operasi mencakup pertimbangan untuk apapun operasinya, khususnya mengambil keputusan medis, obat, dan riwayat alergi yang lengkap dan mengevaluasi klien akan penerimaan mental dan emosional dari prosedur bedah.

Mengkaji kekuatan motorik dan fleksibilitas sendi yang lain sangat penting untuk menentukan masalah potensial yang melibatkan rehabilitasi. Jika klien akut, misalnya dengan ekstremitas gangren dan berhubungan dengan demam, disorientasi, dan ketidakseimbangan elektrolit, perawat memantau dampak perubahan sirkulasi di ekstremitas, seperti rasa sakit yang parah, perubahan warna, dan kurangnya denyut perifer. Hal ini Sangat penting untuk diinformasikan kepada dokter, berbagai dampak yang terjadi tersebut bisa membuat operasi dapat menjadi emergency.

Intervensi keperawatan bertujuan untuk mengurangi rasa sakit dan kecemasan dan dukungan klien karena ia mulai berduka kehilangan anggota badan dan beradaptasi terhadap perubahan yang potensial. Perawat mengelola analgesik sebelum operasi untuk klien dengan sever pain. Tindakan kenyamanan lainnya termasuk penanganan 
ekstremitas nyeri dengan lembut, meninggikan tungkai yang bengkak, mendorong keluarga untuk hadir dan memberikan dukungan, terutama pada saat-saat klien sendirian, membantu klien untuk mengekspresikan keprihatinan, dan mengklarifikasi salah persepsi.

Sebelum operasi, perawat menjelaskan semua persiapan preoperative secara rutin dan menegaskan apa yang dokter telah didiskusikan dengan klien dan keluarga tentang sejauh mana cacat fisik; implikasi psikologis, estetika, sosial, dan dampak kepada keterampilan; dan berbagai kemungkinan yang realistis untuk merestorasi prostetik. Perawat harus berhati-hati dalam menjawab pertanyaan tentang peralatan prosthetic dan penggunaannya karena hal ini senantiasa ada kemungkinan bahwa amputasi mungkin perlu melibatkan lebih banyak anggota badan daripada yang diantisipasi. Selain itu, perawat menjelaskan manajemen pasca operasi, seperti bernapas dalam, batuk effektif, penentuan posisi, dan latihan secara rutin dan mendorong klien untuk berlatih jika jika memungkinkan kondisi klien.

Klien bervariasi dalam reaksi mereka terhadap hilangnya yang akan terjadi dari anggota badan. Besarnya kesedihan dianggap sebanding dengan makna simbolis dari bagian tersebut dan tingkat resultan dari kecacatan dan deformitas. Rasa marah dan depresi adalah emosi yang umum. Perawat mengakui perasaan klien dan tetap obyektif dan tidak menghakimi sebagai klien mengekspresikan respon emosional negatif. Meyakinkan klien bahwa reaksi nya normal mungkin memberikan kenyamanan. Perawat seharusnya tidak malu, mengkritik, atau meremehkan perilaku klien.

Seberapa baik klien dapat mengatasi biasanya tergantung pada pengalaman sebelumnya dan bagaimana ia telah berurusan dengan kejadian sebelumnya. Perawat melindungi klien dari tambahan sumber stres. Meskipun klien sibuk dengan potensi kerugian, perawat tidak harus membuat tuntutan yang tidak perlu atau mengharapkan partisipasi penuh dalam rencana perawatan. Perawat memberikan bantuan kegiatan pada waktu lain klien dapat melakukan secara mandiri. Perawat juga mendorong tidur yang cukup dan mendiskusikan teknik yang dapat telah berhasil digunakan di masa lalu dan mendorong mereka mengulang untuk mengatasinya. Membina komunikasi dengan anggota keluarga atau teman-teman untuk memberikan dukungan (Timby \& Smith, 2010). 
Pada masa post operatif, perawat harus berusaha untuk mempertahankan tanda-tanda vital, karena pada amputasi, khususnya amputasi ekstremitas bawah diatas lutut merupakan tindakan yang mengancam jiwa. Perawat melakukan pengkajian tanda-tanda vital selama klien belum sadar secara rutin dan tetap mempertahankan kepatenan jalas nafas, mempertahankan oksigenisasi jaringan, memenuhi kebutuhan cairan darah yang hilang selama operasi dan mencegah injuri.

Daerah luka diperhatikan secara khusus untuk mengidentifikasi adanya perdarahan masif atau kemungkinan balutan yang basah, terlepas atau terlalu ketat. Selang drainase benarbenar tertutup. Kaji kemungkinan saluran drain tersumbat oleh clot darah. Awal masa postoperatif, perawat lebih memfokuskan tindakan perawatan secara umum yaitu menstabilkan kondisi klien dan mempertahankan kondisi optimum klien. Perawat bertanggungjawab dalam pemenuhan kebutuhan dasar klien, khususnya yang dapat menyebabkan gangguan atau mengancam kehidupan klien.

Berikutnya fokus perawatan lebih ditekankan pada peningkatan kemampuan klien untuk membentuk pola hidup yang baru serta mempercepat penyembuhan luka. Tindakan keperawatan yang lain adalah mengatasi adanya nyeri yang dapat timbul pada klien seperti nyeri Panthom Limb dimana klien merasakan seolah-olah nyeri terjadi pada daerah yang sudah hilang akibat amputasi.

Kondisi ini dapat menimbulkan adanya depresi pada klien karena membuat klien seolaholah merasa 'tidak sehat akal' karena merasakan nyeri pada daerah yang sudah hilang. Dalam masalah ini perawat harus membantu klien mengidentifikasi nyeri dan menyatakan bahwa apa yang dirasakan oleh klien benar adanya.

Amputasi dianggap selesai setelah dipasang prostesis yang baik dan berfungsi.

Ada 2 cara perawatan post amputasi yaitu :

a) Rigid dressing

Yaitu dengan menggunakan plaster of paris yang dipasang waktu dikamar operasi.

Pada waktu memasang harus direncanakan apakah penderita harus immobilisasi 
atau tidak. Bila tidak diperlukan pemasangan segera dengan memperhatikan jangan sampai menyebabkan konstriksi stump dan memasang balutan pada ujung stump serta tempat-tempat tulang yang menonjol. Keuntungan cara ini bisa mencegah oedema, mengurangi nyeri dan mempercepat posisi berdiri.

Setelah pemasangan rigid dressing bisa dilanjutkan dengan mobilisasi segera, mobilisasi setelah $7-10$ hari post operasi setelah luka sembuh, setelah $2-3$ minggu, setelah stump sembuh dan mature. Namun untuk mobilisasi dengan rigid dressing ini dipertimbangkan juga faktor usia, kekuatan, kecerdasan penderita, tersedianya perawat yang terampil, therapist dan prosthetist serta kerelaan dan kemauan dokter bedah untuk melakukan supervisi program perawatan.

Rigid dressing dibuka pada hari ke $7-10$ post operasi untuk melihat luka operasi atau bila ditemukan cast yang kendor atau tanda-tanda infeksi lokal atau sistemik.

Kelebihan dressing rigid:

- Melindungi stump dari trauma.

- Mengurangi rasa sakit stump.

- Memungkinkan untuk awal bantalan berat.

- Salah satu cara terbaik untuk mengendalikan pembengkakan.

- Menjaga Rentang baik Motion (ROM) dari pada lutut atau siku

Kelemahan dan kontraindikasi untuk dressing rigid:

- Orang dengan amputasi harus dipantau sering untuk jangka waktu 2 sampai 4 minggu atau sampai penyembuhan terjadi.

- Sayatan tidak dapat diperiksa secara sering.

- Terbaik untuk digunakan saat penyebab amputasi adalah trauma dan tidak ada proses penyakit yang mendasarinya.

- Bahan cast dan seorang ahli untuk menerapkan harus tersedia.

- Tidak bisa digunakan dengan sayatan luka yang terinfeksi

b) Soft dressing

Yaitu bila ujung stump dirawat secara konvensional, maka digunakan pembalut steril yang rapi dan semua tulang yang menonjol dipasang bantalan yang cukup. Harus diperhatikan penggunaan elastik verban jangan sampai menyebabkan konstriksi pada stump. Ujung stump dielevasi dengan meninggikan kaki tempat 
tidur, melakukan elevasi dengan mengganjal bantal pada stump tidak baik sebab akan menyebabkan fleksi kontraktur. Biasanya luka diganti balutan dan drain dicabut setelah 48 jam. Ujung stump ditekan sedikit dengan soft dressing dan pasien diizinkan secepat mungkin untuk berdiri setelah kondisinya mengizinkan.

Biasanya jahitan dibuka pada hari ke 10 - 14 post operasi. Pada amputasi diatas lutut, penderita diperingatkan untuk tidak meletakkan bantal dibawah stump, hal ini perlu diperhatikan untuk mencegah terjadinya kontraktur.

Kapan harus menggunakan dressing yang lembut (WHO, 2004):

- Ketika luka operasi perlu diperiksa sering kali.

- Ketika terdapat drainase luka, membutuhkan perubahan yang sering.

- Ketika balutan material sudah tersedia.

- Ketika pengasuh memiliki sedikit keterampilan dengan penerapan dressing yang kaku.

- Ketika bahan untuk dressing yang kaku tidak tersedia

c) Rigid Dressing Removable

Suatu dressing yang kaku dapat dilepas dengan menggunakan socket cast tunggal, yang dikombinasikan dengan lapisan kaos kaki atau kain untuk menutupi ruang yang terjadi sebagai limb yang menyusut. Teknik ini dianjurkan bagi orang dengan amputasi bawah lutut saja. Hal ini harus dilepaskan hanya untuk waktu yang singkat untuk melihat luka atau membersihkan limb.

Kelebihan dressing yang kaku-dapat dilepas:

- Melindungi stump dari trauma.

- Memungkinkan pemeriksaan sayatan secara sering.

- Cara yang baik mengurangi pembengkakan.

- Mengurangi sakit stump

Kelemahan / Kontraindikasi berpakaian dapat dilepas yang kaku:

- Harus memiliki material casting dan orang terampil yang tersedia.

- Tidak bisa digunakan ketika garis insisi tidak penyembuhan dengan baik. 
- Harus diperiksa satu kali seminggu dengan orang yang membuat dressing

Penelitian tahun 2005 membandingkan standard soft dressing (SSD) dengan rigid dressing (RRD) pada pasien amputasi trans-tibial menunjukan Tidak ada perbedaan yang signifikan antara parameter lain yang diukur termasuk waktu untuk pemasangan prostetik, lama tinggal di rumah sakit, kejadian stump rusak, dan waktu yang dibutuhkan volume stump untuk menstabilisasi. Insiden kerusakan stump akibat terjatuh juga dicatat, hasilnya menunjukkan bahwa RRDs dapat memproteksi stump yang baru dari trauma (Deutsch, English, Vermeer, Murray, \& Condous, 2005). Lain halnya penelitian yang dilakukan (Ladenheim, Oberti-Smith, \& Tablada, 2007) Hasil penelitian menunjukkan bahwa pasien dalam kelompok Rigid Dressing sebelum fabrikasi untuk prostesis khusus pertamanya. rata-rata 58 hari setelah operasi dibandingkan 84 hari bagi mereka dalam kelompok soft dressing, perbedaan yang signifikan secara statistik. itu menyimpulkan bahwa hasil klinis penyembuhan luka membaik dengan rigid dressing dibandingkan dengan dressing lembut. Penelitian lain rigid dressing juga mempercepat penurunan volume edema dibandingkan dengan elastic bandge (Hidayati, Ilyas, Murdana, Tarigan, \& Werdhani, 2013). Sebuah penelitian retrospektif pada Below Knee Amputation (BKA) menunjukan BKA memiliki waktu penyembuhan secara signifikan lebih cepat, yang diukur dengan waktu yang akan dicast untuk prostesis, ketika rigid dressing digunakan dibandingkan dengan soft dressing. Pertimbangan harus diberikan untuk penggunaan rigid dressing setelah BKA untuk mempercepat penyembuhan dan mendorong ambulation lebih awal(Sumpio, Shine, Mahler, \& Sumpio, 2013).

\section{Perawatan stump dan bandage}

Perawatan stump penting dalam mencegah kerusakan kulit dan memberikan kecocokan pemasangan prostesis. Suatu rutinitas perawatan kulit sehari-hari membersihkan dan memeriksa untuk kemerahan, lecet, dan setiap kerusakan kulit sangat penting. Sampai insisi telah sembuh, pasien akan membutuhkan analgesik sekitar 30 menit sebelum perawatan stump dan mengubah dressing. Anjurkan pasien untuk mencuci stump dengan sabun lembut dan air hangat. stump ini harus dikeringkan secara menyeluruh sebelum menerapkan dressing, perban kompresif, atau menyusutnya perangkat. Seringkali pasien dapat meninggalkan stump terbuka ke udara sekitar 10 menit untuk memungkinkan stump benar-benar kering. Kali ini juga memungkinkan pasien berkesempatan untuk 
melihat stump dan mulai menerima perubahan. Langkah selanjutnya dalam perawatan stump adalah massage. Hal ini dilakukan secara rutin untuk mengurangi sensitivitas limb residu. Pasien harus didorong untuk melakukan perawatan stump dan pijat untuk meningkatkan kemandirian pasien dan membantu pasien menerima amputasi (Daniels \& Nicoll, 2012).

Segera setelah operasi dressing steril dijaga di posisi bersama dengan balutan kompresif. Perban kompresif harus diterapkan dengan menggunakan angka delapan metode (Gambar 60-15) dengan kompresi besar diaplikasikan sampai akhir bagian distal dari stump untuk mencegah edema. Anjurkan pasien untuk berhati-hati dalam menggunakan klip atau pin dalam mengamankan dressing kompresi karena berisiko menyebabkan luka atau lecet limb residu.

a. Stump Care

- Mengkaji covering atas tunggul sesering mungkin untuk menentukan jenis dan jumlah drainase dari luka bekas operasi. Diharapkan beberapa mengalir darah, tetapi jika dressing kasa yang digunakan, mungkin perlu untuk dikuatkan.

- Simpanlah tourniquet di samping tempat tidur dan jika perdarahan terjadi, menerapkannya dan memberitahu dokter.

- Umumnya, meninggikan stump untuk pertama 24 sampai 48 jam untuk mencegah edema. Dalam beberapa kasus, seperti amputasi AK, posisi Trendelenburg sedikit lebih disukai daripada meninggikan stump diatas bantal karena bagian pinggul membungkuk mempromosikan kontraktur fleksi.

- Jika klien memiliki rigid dressing dengan walking pylon, kendurkan harness, yang menggantungkan cast mulai dari pinggang, ketika klien di tempat tidur. Sedikit kencangkan harness ketika klien rawat jalan (Timby \& Smith, 2010).

b. Bandage

Sebelum prostesis permanen dapat dilakukan, stump harus mengecilkan dan berbentuk. Hal ini dilakukan dengan perban elastis yang dibalut sekitar stump. Tidak seperti stump kaki, stump lengan tidak memerlukan sebagai besar penyusutan selama periode lebih lama. Berbagai teknik balutan yang tepat, tetapi beberapa prinsip yang diamati:

- Lepas dan kembali membungkus perban setidaknya dua kali selama hari dan sebelum klien retires untuk malam. 
- perban persendian dengan cara dalam posisi netral atau diperpanjang.

- Hindari bergantian melingkar, yang bertindak seperti tourniquet dan mempengaruhi aliran darah (Timby \& Smith, 2010).







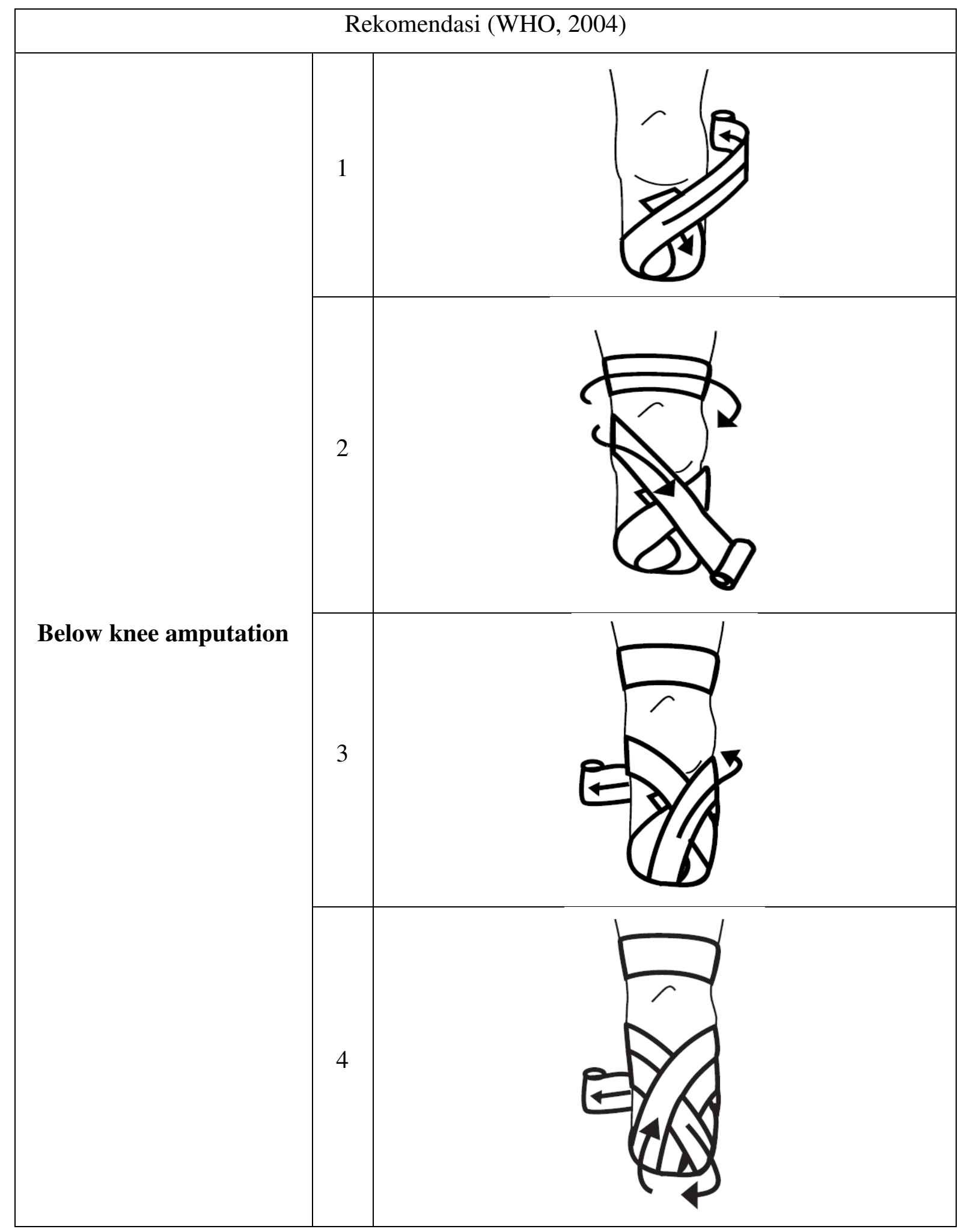




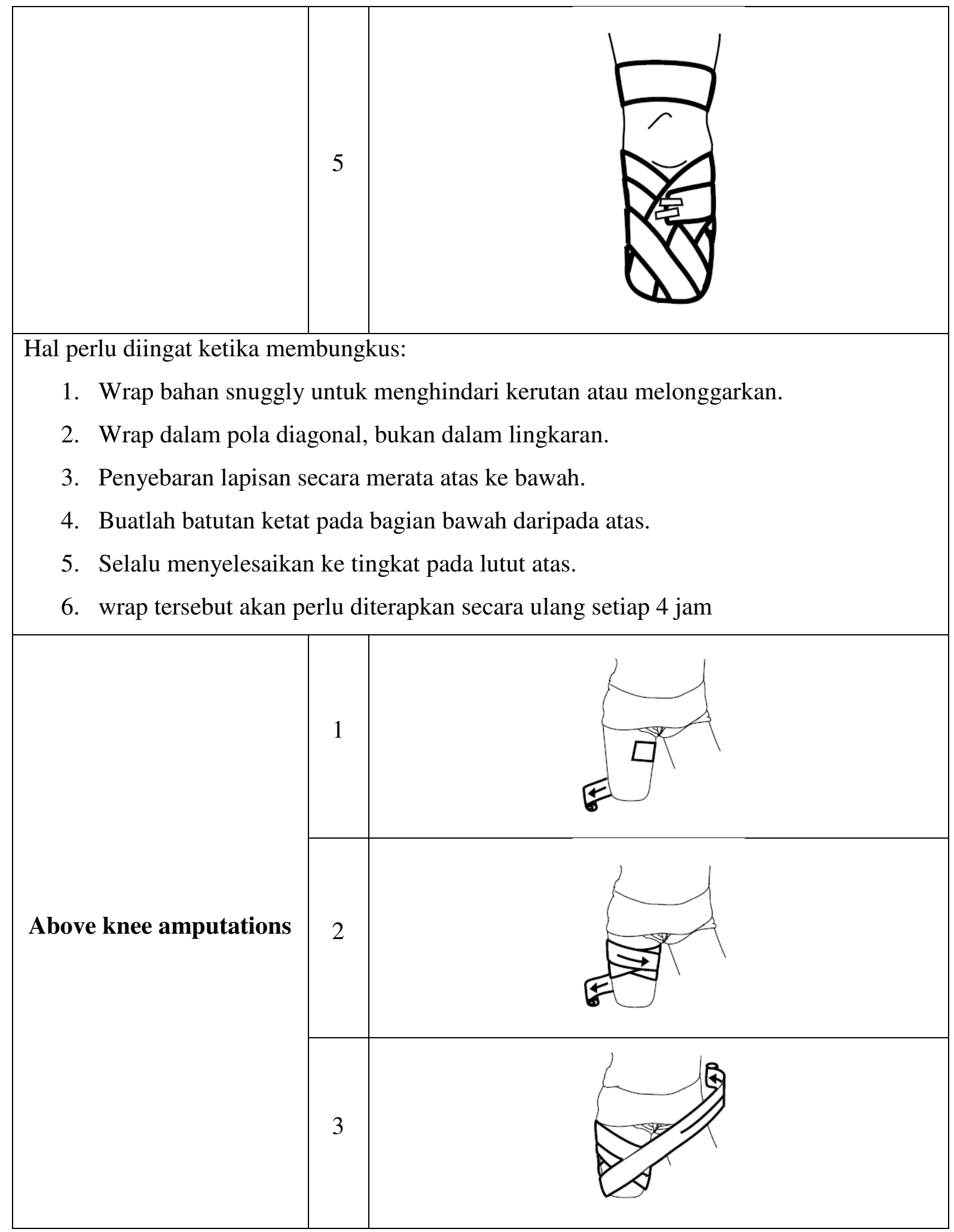




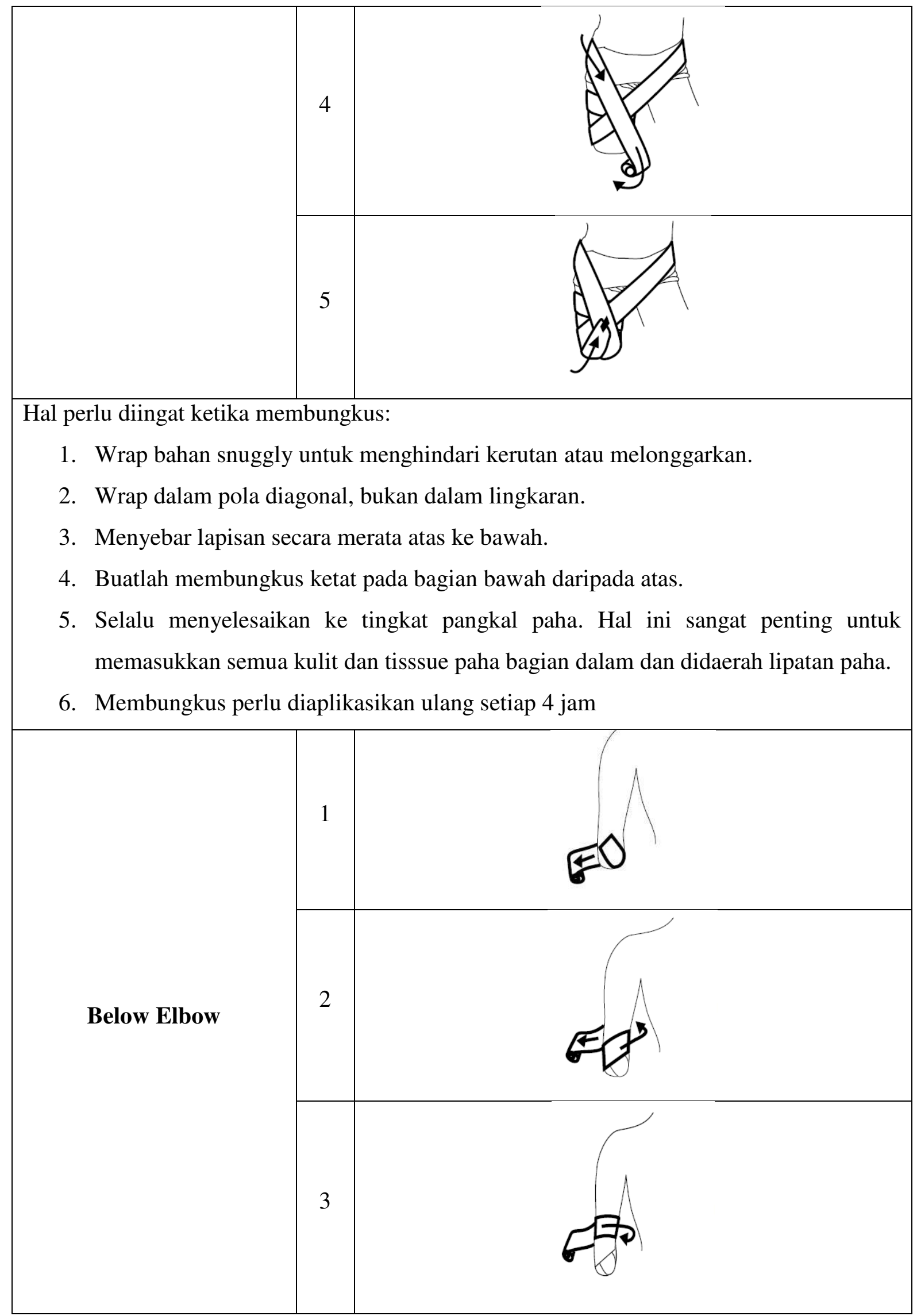




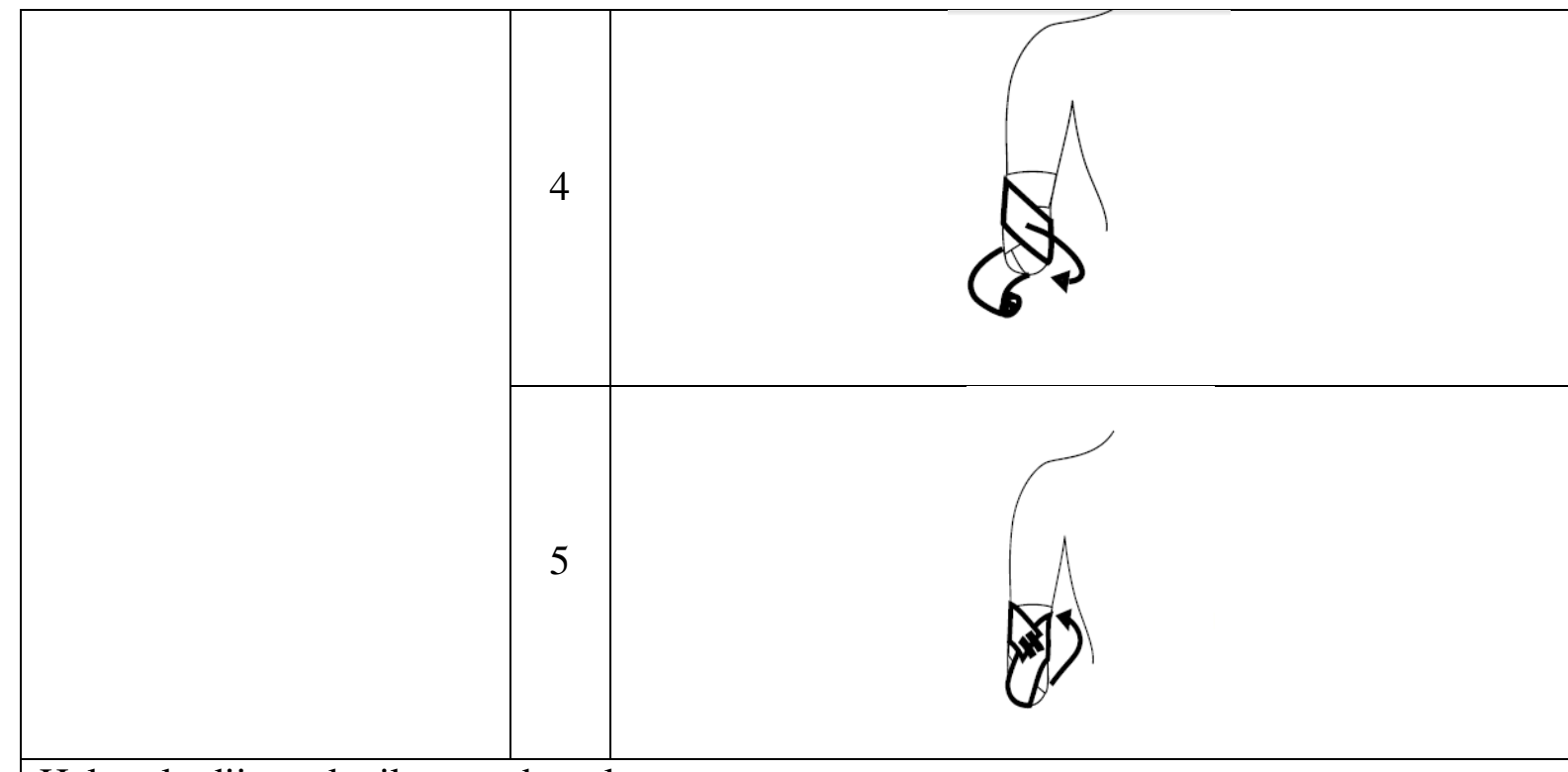

Hal perlu diingat ketika membungkus:

1. Wrap bahan snuggly untuk menghindari kerutan atau melonggarkan.

2. Wrap dalam pola diagonal, bukan dalam lingkaran.

3. Menyebar lapisan secara merata atas ke bawah.

4. Buatlah membungkus ketat pada bagian bawah daripada atas.

5. Pada amputasi siku bawah senantiasa wrap di atas siku.

6. Membungkus perlu diaplikasikan ulang setiap 4 jam

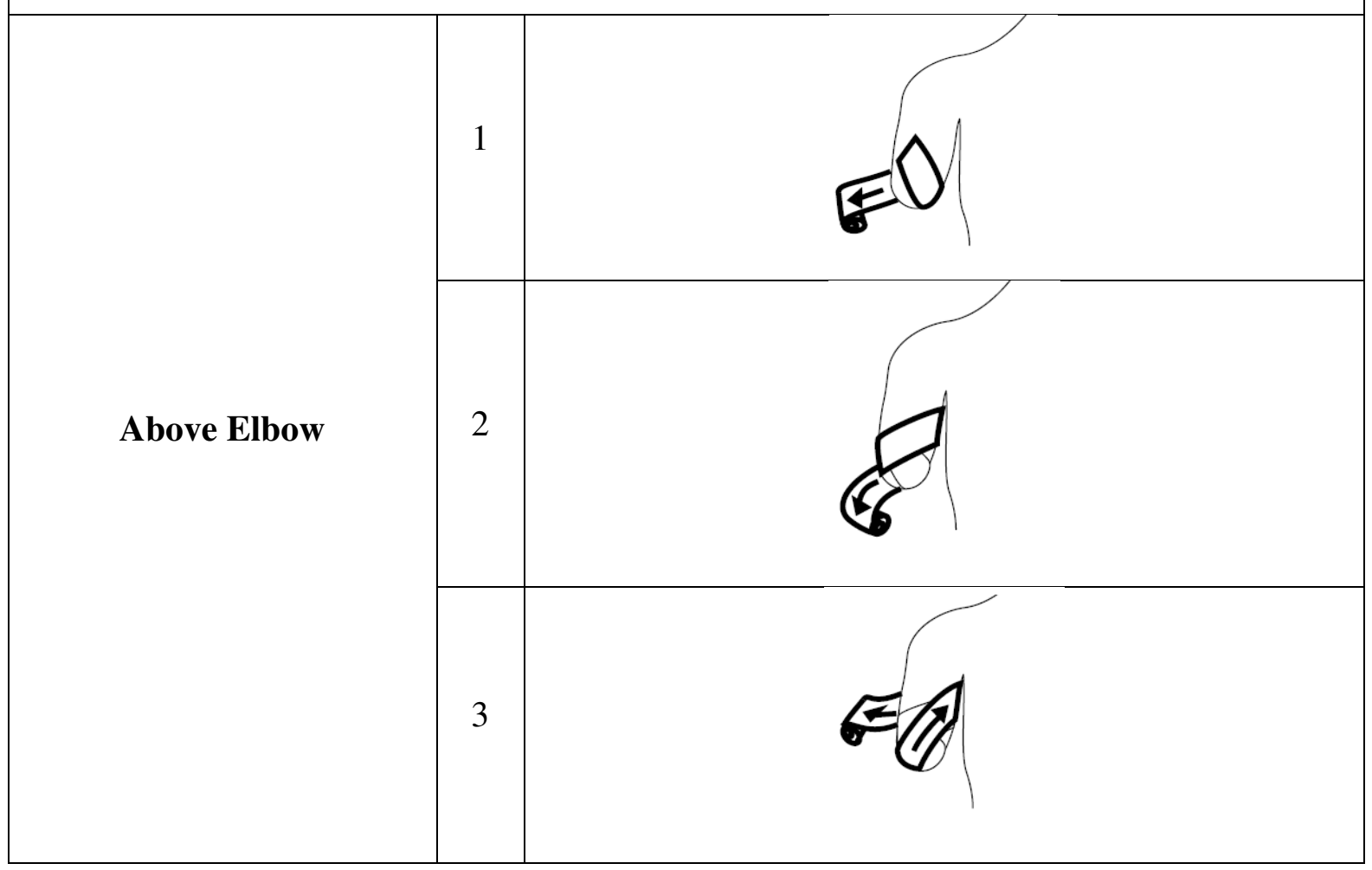




\begin{tabular}{l} 
Hal perlu diingat ketika membungkus: \\
1. Wrap bahan snuggly untuk menghindari kerutan atau melonggarkan. \\
2. Wrap dalam pola diagonal, bukan dalam lingkaran. \\
3. Menyebar lapisan secara merata atas ke bawah. \\
4. Buatlah membungkus ketat pada bagian bawah daripada atas. \\
5. Pada siku atas membungkus bagian dada. \\
6. Membungkus perlu diaplikasikan ulang setiap 4 jam. \\
\hline
\end{tabular}

\section{c. Posisi stump}

Sebelum pasien dipasang untuk prosthesis, sebuah Shrinker stump yang digunakan mengurangi edema dan untuk membentuk limb residu untuk prostesis. Mencegah komplikasi lain, misalnya perdarahan, kerusakan neurovaskular, infeksi, abduksi, rotasi eksternal, dan kontraktur fleksi, pedoman untuk penentuan posisi stump harus diikuti. Dalam 24 jam pertama setelah operasi ekstremitas dapat ditinggikan untuk mengurangi edema. Dalam 24 jam pertama setelah operasi ekstremitas dapat ditinggikan untuk mengurangi edema. Setelah periode awal ini waktu stump tidak harus ditinggikan atau diganjal dengan bantal karena berisiko menyebabkan kontraktur. Posisi bergantung harus dihindari untuk membantu sirkulasi dan mencegah peningkatan edema. Meskipun pasien duduk di kursi atau di toilet stump harus dipertahankan pada permukaan yang empuk di tingkat yang sama dengan kursi atau toilet. Pasien harus diinstruksikan untuk menjaga kaki diposisikan sama untuk mencegah abduksi pinggul. Pasien harus didorong untuk mengubah posisi setiap jam 
sementara di kursi dan setiap dua jam di tempat tidur. Pasien dapat mencapai hal ini dengan menggunakan trapeze. Pasien juga harus diinstruksikan untuk berbaring prone beberapa kali sehari selama 10-20 menit untuk mendorong ekstensi panggul dan mencegah kontraktur fleksi pinggul (Daniels \& Nicoll, 2012a).

\section{Protestik}

Prostesis adalah perangkat buatan yang menggantikan sebagian atau seluruh ekstremitas yang hilang. Selama bertahun-tahun, desain prostesis telah membaik, dan mereka menjadi lebih ringan dan dapat diandalkan. Penggunaan teknologi komputer telah menghasilkan lebih pas peralatan prosthetic yang lebih fungsional dan natural mencari. Klien dilengkapi dengan prostetik sesegera mungkin setelah operasi; kadang-kadang ahli bedah memasang prostesis sementara sementara klien masih dibius. Kaki yang prostesis yang paling sukses. Rok dan celana bisa menutupi prostesis kaki, yang dapat dilengkapi dengan sepatu yang cocok. Terapis dan perawat yang terlatih khusus membantu orang belajar untuk berjalan dengan prostesis baru.

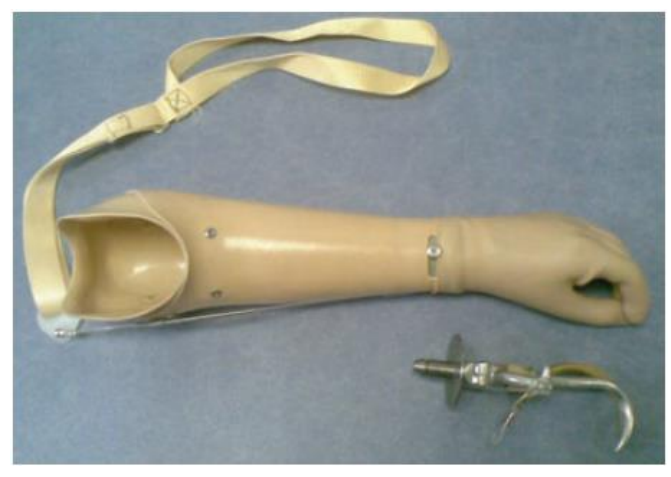

Biasanya, prosthesis lengan lebih rumit karena tangan merupakan motor yang indah dan organ sensorik. Tangan tiruan berfungsi umumnya tidak terlihat nyata. Di atas-the-siku diamputasi dapat menggunakan protesa baik fungsional maupun kosmetik. Sebuah tangan prostetik praktis kuno dengan hook mekanik, yang terdiri dari garpu logam yang dipasang berlawanan satu sama lain untuk menggantikan jari dan ibu jari. Penempatan oposisi diperlukan untuk memungkinkan diamputasi untuk mengadakan artikel secara normal. Klien dapat mengaktifkan prostesis mereka dengan gerakan tubuh atau sumber daya eksternal elektrik (Rosdahl \& Kowalski, 2012).

\section{Evidance Based Nursing}

Pasien dengan amputasi begitu kompleks permasalahan baik secara fisik, psikis, social dan spiritual. Sebuah studi menunjukkan bahwa amputasi tungkai bawah secara 
signifikan mempengaruhi citra tubuh pasien dan kualitas hidup. Harga diri tampaknya menjadi aspek yang independen, yang tidak terpengaruh oleh amputasi tungkai bawah. Namun, harga diri dipengaruhi secara signifikan oleh sensasi nyeri phantom (Holzer et al., 2014). Penelitian lain yang dilakukan (Peirano, 2010), mengemukakan kepuasan kehidupan dengan amputasi, kesehatan secara umum, dan skor integrasi sosial yang tertinggi di antara individu yang terlibat dalam eksistensi spiritualitas dan kurang tinggi di kalangan individu yang terlibat dalam spiritualitas agama. Dalam meningkatkan kualitas hidup pasien dengan amputasi dapat dengan pendekatan spiritual.

Kembali kepada penelitian (Holzer et al., 2014), merekomendasikan untuk meningkatkan citra tubuh dan kualitas hidup pasien harus terbebas dari komplikasi nyeri. Nyeri Amputasi dapat menimbulkan di bagian tubuh yang telah diamputasi (nyeri phantom) atau di lokasi amputasi (stump nyeri), atau keduanya. Nyeri phantom dan nyeri tunggul yang kompleks dan multidimensi dan patofisiologi yang mendasari masih belum jelas. Perlakuan menjadi andalan untuk nyeri phantom dan nyeri stump sebagian besar adalah farmakologis. Kondisi tersebut tetap menjadi beban berat bagi mereka yang terkena dampaknya (Mulvey, Bagnall, Johnson, \& Marchant, 2010). Terdapat dua level utama di mana intervensi yang paling berhasil menangani nyeri phantom: gejala yang intervensi farmakologis tertentu dan disesuaikan paradigma psikologis, secara fisik dan perilaku. Intervensi bedah kadang-kadang berupaya dengan berbagai tingkat keberhasilan, misalnya, pengelolaan neuromas stump, yang biasanya melibatkan prosedur bedah invasif atau suntikan ke dalam ujung saraf (Giummarra \& Moseley, 2011).

Salah satu penelitian terbaru, Phantom limb pain (PLP) diyakini terkait dengan reorganisasi korteks sensorik yang berbeda. sebuah kasus pasien dengan ekstremitas PLP atas yang berhasil diobati dengan transcranial magnetic stimulation yang berulang (RTM). Rangsangan $1 \mathrm{~Hz}$ pada korteks sensorik yang sesuai dengan bidang amputasi lima kali seminggu. Setelah 4 sesi, nyeri pasien menurun dari Visual Analog Scale dari 5 sampai 2. Waktu stimulasi $10 \mathrm{~Hz}$ ditambahkan dan setelah 28 sesi, rasa sakit berkurang 2-1. Kesimpulan: Temuan kami mendukung bahwa RTM merupakan modalitas yang efektif untuk pasien ini dalam mengobati PLP-nya (Grammer, Williams-Joseph, Cesar, Adkinson, \& Spevak, 2015). 


\section{Nursing Theory Amputation}

Pasien dengan kasus amputasi mengalami gangguan bukan hanya fisik akan tetapi psikis, social dan spiritual. Proses kehilangan yang dicintai sangat menyakitkan, apalagi bagian dari tubuh. Salah satu teori yang mendasari praktek keperawatan professional adalah memandang manusia sebagai makhluk social sebagai holistic yang meliputi dimensi fisiologis, psikologis, sosiokultural dan spiritual sebagai kesatuan yang utuh. Apabila satu dimensi terganggu akan mempengaruhi dimensi yang lainnya.

Model pendekatan Sister Calista Roy, Selain konsep holistic juga dikembangkan teori model adaptasi. Teori adaptasi ini menggunakan pendekatan yang dinamis, peran perawat dalam membelikan asuhan keperawatan dengan memfasilitasi kemampuan klien untuk adaptasi dalam menghadapi perubahan kebutuhan dasarnya. Dalam proses adaptasi Roy memandang manusia secara holistic yang satu kesatuan.

Erikson, Tomlin dan Swain (Alligood, 2014), juga memandang bahwa manusia adalah keseluruhan terdiri dari banyak subsistem yang paling ketergantungan dan tidak terpisahkan. Dengan model adaptasi Roy, perawat dapat meningkatkan penyesuaian diri pasien dalam menghadapi tantangan yang berhubungan dengan sehat sakit, meningkatkan penyesuaian diri pasien menuju adaptasi dalam menghadapi stimulus. Kesehatan diasumsikan sebagai hasil dari adaptasi pasien dalam menghadapi stimulus yang datang dari lingkungan. Dalam model adaptasi Roy terdapat proses keperawatan yang dimulai dari mengkaji prilaku dan faktor-faktor yang mempengaruhi, mengindentifikasi masalah, menetapkan tujuan dan mengevaluasi hasil.

Roy menjelaskan bahwa keperawatan sebagai proses interpersonal yang diawal adanya kondisi maladaptasi akibat perubahan lingkungan baik internal maupun eksternal. Peran perawat adalah memfasilitasi potensi klien untuk mengadakan adaptasi dalam menghadapi perubahan kebutuhan dasarnya untuk mempertahankan homeostasis atau integritasnya.

Stimulus yang menimbulkan akibat pada manusia terbagi menjadi tiga yaitu: a) stimulus fokal yaitu stimulus yang langsung berhadapan saat ini, b) stimulus kontekstual, yaitu semua stimulus lain yang dialami seseorang baik internal maupun eksternal yang mempengaruhi situasi dan dapatmenimbulkan respon negative pada stimulus fokal, c) Stimulus Residual: berupa ciri-ciri tambahan yang ada relevan dengan situasi yang ada 
tetapi sukar untuk diobservasi meliputi kepercayaan, sikap, sifat individu berkembang sesuai dengan pengalaman masa laluyang dapat membantu untuk belajar toleransi terhadap sesuatu.

Roy mengemukakan pandangan tentang manusia sebagai penerimaan asuhan keperawatan dalam kaitannya dengan teori adaptasi, bahwa manusia makhluk biopsikososial secara utuh (holistik). Adaptasi dijelaskan oleh Roy melalui sistem efektor/ model adaptasi yang terdiri dari empat faktor yaitu: a) fisiologis terdiri dari oksigen, eliminasi, nutrisi, aktivitas dan istirahat, sensori, cairan dan elektrolit. Fungsi syarat fungsi endokrin dan fungsi reproduksi. B) konsep diri: menunjukan pada nilai kepercayaan, emosi, perhatian, cita-cita yang diberikan untuk menyatakan keadaan fisik; c) fungsi peran menggambarkan hubungan interaksi seseorang dengan orang lain yang tercemin pada peran primer, skunder dan tersier; d) Saling ketergantungan (independen): mengindentifikasi nilai manusia, cinta dan keseriusan. Proses ini terjadi dalam hubungan manusia dengan individu dan kelompok.

Aplikasi model adaptasi Roy dalam proses keperawatan terdiri dari dua tahap pengkajian pengkajian yaitu: tahap pertama meliputi pengumpulan data oleh perawat berfokus pada empat model adaptasi yaitu fisiologis, konsep diri, fungsi peran dan interindepensi melalui pendekatan sistem dan memandang manusia sebagai makhluk bio-psiko-sosial secara utuh.

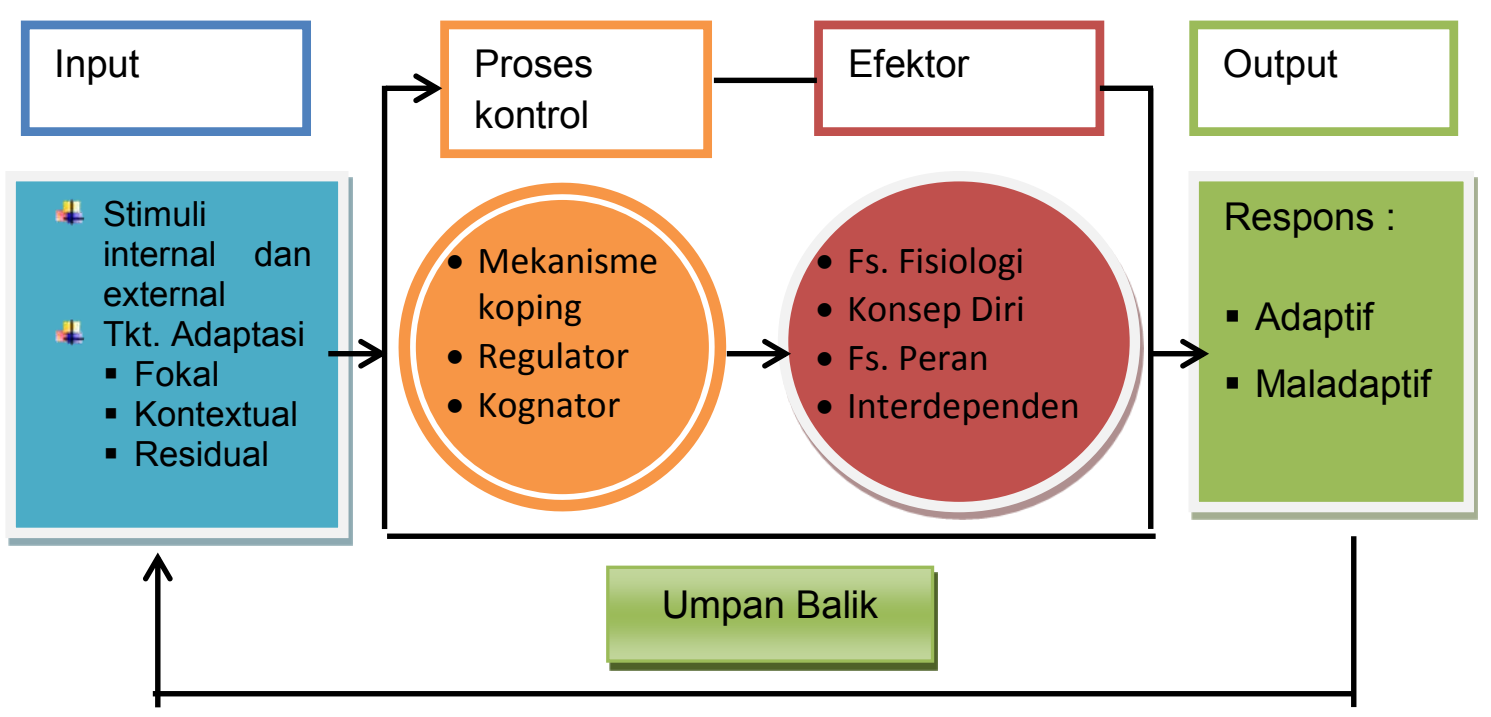




\section{Pathway}



Diadopsi dari (Mutaqin, 2012) 


\section{Nursing Proses}

Kegiatan keperawatan yang dilakukan pada klien dapat dibagi dalam tiga tahap yaitu pada tahap preoperatif, tahap intraoperatif, dan pada tahap post operatif.

a. Pre Operatif . Pada tahap praoperatif, tindakan keperawatan lebih ditekankan pada upaya untuk mempersiapkan kondisi fisik dan psikolgis klien dalam menghadapi kegiatan operasi. Pada tahap ini, perawat melakukan pengkajian yang berkaitan dengan kondisi fisik,khususnya yang berkaitan erat dengan kesiapan tubuh untuk menjalani operasi.

b. Intra Operatif. Pada masa ini perawat berusaha untuk tetap mempertahankan kondisi terbaik klien. Tujuan utama dari manajemen (asuhan) perawatan saat ini adalah untuk menciptakan kondisi opyimal klien dan menghindari komplikasi pembedahan. Perawat berperan untuk tetap mempertahankan kondisi hidrasi cairan, pemasukan oksigen yang adekuat dan mempertahankan kepatenan jalan nafas, pencegahan injuri selama operasi dan dimasa pemulihan kesadaran. Khusus untuk tindakan perawatan luka, perawat membuat catatan tentang prosedur operasi yang dilakukan dan kondisi luka, posisi jahitan dan pemasangan drainage. Hal ini berguna untuk perawatan luka selanjutnya dimasa postoperatif

c. Post Operatif. Pada masa post operatif, perawat harus berusaha untuk mempertahankan tanda-tanda vital, karena pada amputasi, khususnya amputasi ekstremitas bawah diatas lutut merupakan tindakan yang mengancam jiwa. Perawat melakukan pengkajian tanda-tanda vital selama klien belum sadar secara rutin dan tetap mempertahankan kepatenan jalas nafas, mempertahankan oksigenisasi jaringan, memenuhi kebutuhan cairan darah yang hilang selama operasi dan mencegah injuri. Daerah luka diperhatikan secara khusus untuk mengidentifikasi adanya perdarahan masif atau kemungkinan balutan yang basah, terlepas atau terlalu ketat. Selang drainase benar-benar tertutup. Kaji kemungkinan saluran drain tersumbat oleh clot darah. Awal masa postoperatif, perawat lebih memfokuskan tindakan perawatan secara umum yaitu menstabilkan kondisi klien dan mempertahankan kondisi optimum klien. Perawat bertanggungjawab dalam pemenuhan kebutuhan dasar klien, khususnya yang dapat menyebabkan gangguan atau mengancam kehidupan klien. Berikutnya fokus perawatan lebih ditekankan pada peningkatan kemampuan klien untuk membentuk pola hidup yang baru serta mempercepat penyembuhan luka. 
Tindakan keperawatan yang lain adalah mengatasi adanya nyeri yang dapat timbul pada klien seperti nyeri Panthom Limb dimana klien merasakan seolah-olah nyeri terjadi pada daerah yang sudah hilang akibat amputasi. Kondisi ini dapat menimbulkan adanya depresi pada klien karena membuat klien seolah-olah merasa 'tidak sehat akal' karena merasakan nyeri pada daerah yang sudah hilang. Dalam masalah ini perawat harus membantu klien mengidentifikasi nyeri dan menyatakan bahwa apa yang dirasakan oleh klien benar adanya.

\section{a. Pengkajian}

1) Biodata

2) Keluhan utama: Keterbatasan aktivitas, gangguan sirkulasi, rasa nyeri,dan gangguan neurosensori

3) Riwayat kesehatan masa lalu: Kelainan muskuloskeletal (jatuh, infeksi, trauma, dan fraktur), cara penanggulangan dan penyakit (amputasi).

4) Riwayat Kesehatan sekarang: kapan timbul masalah, riwayat trauma, penyebab, gejala (tiba-tiba/perlahan), lokasi, obat yang diminum dan cara penanggulangan.

5) Pemeriksaan fisik: keadaan umum dan kesadaran, keadaan integumen (kulit dan kuku), (hipertensi dan takikardi), neurologis (spasme otot dan kesemutan), keadaan ekstremitas, keterbatasan rentang gerak dan adanya kontraktur, dan sisa tungkai (kondisi dan fungsi).

Pengkajian fisik dilaksanakan untuk meninjau secara umum kondisi tubuh klien secara utuh untuk kesiapan dilaksanakannya tindakan operasi manakala tindakan amputasi merupakan tindakan terencana/selektif, dan untuk mempersiapkan kondisi tubuh sebaik mungkin manakala merupakan trauma/ tindakan darurat. Kondisi fisik yang harus dikaji meliputi :

- Integumen : Kulit secara umum.Lokasi amputasi : Mengkaji kondisi umum kulit untuk meninjau tingkat hidrasi. Lokasi amputasi mungkin mengalami keradangan akut atau kondisi semakin buruk, perdarahan atau kerusakan 
progesif. Kaji kondisi jaringan diatas lokasi amputasi terhadap terjadinya stasis vena atau gangguan venus return.

- Sistem Cardiovaskuler :Cardiac reserve Pembuluh darah: Mengkaji tingkat aktivitas harian yang dapat dilakukan pada klien sebelum operasi sebagai salah satu indikator fungsi jantung. Mengkaji kemungkinan atherosklerosis melalui penilaian terhadap elastisitas pembuluh darah.

- Sistem Respirasi: Mengkaji kemampuan suplai oksigen dengan menilai adanya sianosis, riwayat gangguan nafas.

- Sistem Urinari: Mengkaji jumlah urine 24 jam. Mengkaji adanya perubahan warna, BJ urine

- Cairan dan elektrolit: Mengkaji tingkat hidrasi.. Memonitor intake dan output cairan.

- Sistem Neurologis: Mengkaji tingkat kesadaran klien. Mengkaji sistem persyarafan, khususnya sistem motorik dan sensorik daerah yang akan diamputasi.

- Sistem Mukuloskeletal: Mengkaji kemampuan otot kontralateral.

6) Riwayat Psikososial: reaksi emosional, citra tubuh dan sistem pendukung. Disamping pengkajian secara fisik perawat melakukan pengkajian pada kondisi psikologis (respon emosi) klien yaitu adanya kemungkinan terjadi kecemasan pada klien melalui penilaian klien terhadap amputasi yang akan dilakukan, penerimaan klien pada amputasi dan dampak amputasi terhadap gaya hidup. Kaji juga tingkat kecemasan akibat operasi itu sendiri. Disamping itu juga dilakukan pengkajian yang mengarah pada antisipasi terhadap nyeri yang mungkin timbul. Perawat melakukan pengkajian pada gambaran diri klien dengan memperhatikan tingkat persepsi klien terhadap dirinya, menilai gambaran ideal diri klien dengan meninjau persepsi klien terhadap perilaku yang telah dilaksanakan dan dibandingkan dengan standar yang dibuat oleh klien sendiri, pandangan klien terhadap rendah diri antisipasif, gangguan penampilan peran dan gangguan identitas. 
Adanya gangguan konsep diri antisipasif harus diperhatikan secara seksama dan bersama-sama dengan klien melakukan pemilihan tujuan tindakan dan pemilihan koping konstruktif. Adanya masalah kesehatan yang timbul secara umum seperti terjadinya gangguan fungsi jantung dan sebagainya perlu didiskusikan dengan klien setelah klien benar-benar siap untuk menjalani operasi amputasi itu sendiri. Kesadaran yang penuh pada diri klien untuk berusaha berbuat yang terbaik bagi kesehatan dirinya, sehingga memungkinkan bagi perawat untuk melakukan tindakan intervensi dalam mengatasi masalah umum pada saat pre operatif.

7) Pemeriksaan diagnostik: rontgen (lokasi/luas), CT scan, MRI, arteriogram, darah lengkap dan kreatinin.

8) Pola kebiasaan sehari- hari: nutrisi, eliminasi dan asupan cairan

b. Diagnosa Keperawatan (Nanda Insternational, 2014)

1) Pre Operasi

a) Nyeri Akut (00132) berhubungan dengan agen kerusakan fisik / biologi

b) Ansietas (00071) berhubungan dengan kurang pengetahuan tentang kegiatan perioperatif.

2) Post Operasi

a) Nyeri Akut (00132) berhubungan dengan post op amputasi

b) Resiko sindrom disuse (00040) berhubungan dengan penurunan mobilisasi setelah amputasi

c) Gangguan perawatan diri (mandi (00108), pakaian (00109), makan (00102), toileting (00110)) berhubungan dengan kehilangan bagian tubuh.

d) Berduka (00136) berhubungan dengan hilangnya bagian tubuh

e) Gangguan body image (00118) berhubungan dengan hilangnya bagian tubuh

f) Gangguan Integritas kulit (00046) berhubungan dengan pembdahan amputasi

g) Gangguan mobilitas fisik (00085) berhubungan dengan kehilangan ekstermitas

h) Sindrom nyeri kronik (00255) berhubungan dengan phantom limb

i) Resiko infeksi (00004) berhubungan dengan luka operasi 
c. Nursing Care Plan (Bulechek, Butcher, Dochterman, \& Wagner, 2013; Moorhead, Johnson, Maas, \& Swanson, 2013)

\section{1) Nyeri akut ybd Post op amputasi}

a) Tujuan :

Klien mampu mengontrol nyeri setelah dilakukan tindakan keperawatan 5 x 24 jam

b) Kriteria hasil :

Semua indicator outcome menunjukkan score 5

Nursing Outcome Classification (NOC):

NOC : Level nyeri

NOC : Kontrol nyeri

c) Intervensi :

\section{NIC : Manajemen nyeri}

- Identifikasi nyeri pada klien melalui pengkajian pengalaman nyeri secara teratur, meliputi : PQRST

- Gunakan komunikasi terapeutik agar pasien dapat mengekspresikan nyeri

- Berikan informasi tentang nyeri, seperti penyebab, berapa lama terjadi, dan tingkatan pencegahan

- Ajarkan teknik nafas dalam

- Anjurkan klien untuk melaporkan pengalaman nyeri dan metode menangani nyeri yang terakhir dilakukan

- Berikan analgesic sesuai dengan anjuran

- Evaluasi keefektifan dan tindakan mengontrol nyeri

- Tingkatkan tidur/istirahat yang cukup

- Monitor perubahan nyeri

- Libatkan keluarga untuk mengurangi nyeri

\section{NIC : Analgesik administration}

- Tentukan lokasi, karakteristik, kualitas dan derajat nyeri sebelum pemberian obat

- Cek instruksi dokter tentang jenis obat, dosis dan frekuensi

- Cek riwayat alergi

- Monitor vital sign sebelm dan sesudah pemberian analgesic pertama kali 
- Berikan analgesic tepat waktu terutama saat nyeri hebat

- Evaluasi efektivitas analgesic, tanda dan gejala (efek samping)

\section{2) Resiko infeksi ybd Post op Amputasi}

a) Tujuan :

Klien bebas dari tanda dan gejala infeksi setelah dilakukan tindakan keperawatan 5 × 24 jam

b) Kriteria hasil :

Semua indicator outcome menunjukkan score 5

Nursing Outcome Classification (NOC):

NOC : Wound healing: Primary Intention

c) Intervensi :

\section{NIC : Infection control}

- Batasi pengunjung bila perlu

- Gunakan antimikroba untuk cuci tangan

- Cuci tangan setiap sebelum dan sesudah tindakan keperawatan

- Gunakan baju, sarung tangan sebagai alat pelindung

\section{NIC : Pengendalian infeksi}

- Pantau tanda/gejala infeksi (suhu tubuh, denyut jantung, penampilan luka, suhu kulit, keletihan, sekresi)

- Kaji faktor yang meningkatkan serangan infeksi (usia lanjut,tanggap imun rendah, dan malnutrisi)

- Pantau hasil laboratorium (DPL, hasil-hasil yang berbeda, protein serum, albumin)

- Amati penampilan praktik hygiene pribadi untuk perlindungan terhadap infeksi

- Ajarkan kepada pengunjung untuk mencuci tangan sewaktu masuk dan meninggalkan ruangan pasien

\section{3) Kerusakan integritas kulit ybd pembedahan amputasi}

a) Tujuan : 
Klien memiliki keutuhan dan kelengkapan struktur dan fungsi kulit setelah dilakukan tindakan keperawatan 5 x 24 jam

b) Kriteria hasil:

Semua indicator outcome menunjukkan score 5

Nursing Outcome Classification (NOC):

NOC : Integritas jaringan kulit

c) Intervensi :

\section{NIC : Perawatan luka}

- Buang debris dan bekas plester yang melekat

- Tempatkan area yang terkena pada bak khusus, jika diperlukan

- Lakukan pemijatan disekitar luka untuk merangsang sirkulasi

- Berikan perawatan ulkus, jika diperlukan

- Posisikan untuk menghindari ketegangan pada luka, jika diperlukan 


\section{Daftar Pustaka}

Alligood, M. R. (2014). Nursing Theorists and Their Work (8th ed.). St. Louis, Missouri: Mosby Elsevier Inc.

Berman, A., Snyder, S. J., \& Frandsen, G. (2016). Kozier \& Erb's fundamentals of nursing : concepts, practice, and process. (10th ed.). New Jersey: Pearson Education, Inc.

Bulechek, G. M., Butcher, H. K., Dochterman, J. M., \& Wagner, C. M. (2013). Nursing Interventions Clasification (NIC) (6th ed.). USA: Elsevier Inc.

Daniels, R., \& Nicoll, L. (2012a). Contemporary Medical Surgical Nursing (2nd ed.). Clifton Park: Delmar, Cengage Learning.

Daniels, R., \& Nicoll, L. H. (2012b). Contemporary Medical Surgical Nursing (2nd ed.). New York: Cengage Learning.

Deutsch, A., English, R. D., Vermeer, T. C., Murray, P. S., \& Condous, M. (2005). Removable rigid dressings versus soft dressings: a randomized, controlled study with dysvascular, trans-tibial amputees. Prosthetics and Orthotics International, 29(2), 193200. doi:10.1080/03093640500224295

Giummarra, M. J., \& Moseley, G. L. (2011). Phantom limb pain and bodily awareness: current concepts and future directions. Current Opinion in Anaesthesiology, 24(5), 524 531. doi:10.1097/ACO.0b013e32834a105f

Grammer, G. G., Williams-Joseph, S., Cesar, A., Adkinson, D. K., \& Spevak, C. (2015). Significant Reduction in Phantom Limb Pain After Low-Frequency Repetitive Transcranial Magnetic Stimulation to the Primary Sensory Cortex. Military Medicine, 180(1), e126-e128. doi:10.7205/MILMED-D-14-00236

Hidayati, E. R. N., Ilyas, E., Murdana, I. N., Tarigan, T. J. E., \& Werdhani, R. A. (2013). Efficacy of removable rigid dressing after transtibial amputation in diabetes mellitus patients. Med J Indones, 22(1), 16-21.

Holzer, L. a., Sevelda, F., Fraberger, G., Bluder, O., Kickinger, W., \& Holzer, G. (2014). Body image and self-esteem in lower-limb amputees. PLoS ONE, 9(3). doi:10.1371/journal.pone.0092943

Kirkup, J. (2007). A history of limb amputation. London: Springer-Verlag London Limited.

Ladenheim, E., Oberti-Smith, K., \& Tablada, G. (2007). Results of Managing Transtibial Amputation With a Prefabricated Polyethylene Rigid Removable Dressing. Journal of Prosthetics and Orthotics, 19(1), 2-4. 
Moorhead, S., Johnson, M., Maas, M. L., \& Swanson, E. (2013). Nursing Outcomes Classification (NOC) (5th ed.). USA: Elsevier Inc.

Mulvey, M. R., Bagnall, A.-M., Johnson, M. I., \& Marchant, P. R. (2010). Transcutaneous electrical nerve stimulation (TENS) for phantom pain and stump pain following amputation in adults. Cochrane Database of Systematic Reviews (Online), (5). doi:10.1002/14651858.CD007264.pub2

Murray, C. (2010). Amputation, Prosthesis Use, and Phantom Limb Pain An Interdisciplinary Perspective. New York: Springer Publishing Company, Inc.

Mutaqin, A. (2012). Buku Saku Gangguan Muskuloskeletal: Aplikasi pada Praktek Klinik Keperawatan. (P. E. Karyuni \& M. Ester, Eds.). Jakarta: EGC.

Nanda Insternational. (2014). Nursing Diangnosis Definitions and Classification 2015-2017 (10th ed.). Oxford: Wiley Blackwell.

National Limb Loss Information Center (NLLIC). (2008). Amputation Statistics by Cause Limb Loss in the United States. Retrieved from www.amputee-coalition.org

Peirano, A. H. (2010). Spirituality and Quality of Life Among Individualis with Limb Amputation. University of Phoenix.

Rosdahl, C. B., \& Kowalski, M. T. (2012). Textbook of basic nursing (10th ed.). Philadelphia: Wolters Kluwer Health | Lippincott Williams \& Wilkins.

Shrikhande, G. V., \& McKinsey, J. ames F. (2012). Diabetes and Peripheral Vascular Disease Diagnosis and Management. London: Humana Press.

Smeltzer, S. C., Hinkle, J. L., Bare, B. G., \& Cheever, K. H. (2010). Brunner \& Suddarth's textbook of medical-surgical nursing (12th ed.). Philadelphia: Lippincott Williams \& Wilkins.

Stokvis, A. (2010). Surgical Management of Painful Neuromas. Rotterdam: Proefschrift Erasmus Universiteit Rotterdam.

Sumpio, B., Shine, S. R., Mahler, D., \& Sumpio, B. E. (2013). A Comparison of Immediate Postoperative Rigid and Soft Dressing for Below-Knee Ampuations. Ann Vasc Surg; Elsevier Inc., 27(6), 774-780.

Timby, B. K., \& Smith, N. E. (2010). Introductory Medical Surgical Nursing (10th ed.). 2010: Lippincott Williams \& Wilkins.

Weeks, S. R., Anderson-barnes, V. C., \& Tsao, J. W. (2010). Phantom Limb Pain. The Neurologist, 16(5), 277-286. doi:10.1097/NRL.0b013e3181edf128

WHO. (2004). A Manual for the Rehabilitation of People with Limb Amputation. 